$\underline{\text { Research Articles }}$

\title{
Investigation of Innovation in Wine Industry via Meta-Analysis
}

\author{
Ali Dogru $^{1}$ (D), Joseph Peyrefitte ${ }^{1}$ \\ 1 School of Management, University of Southern Mississippi \\ Keywords: innovation, wine industry, meta-analysis, narrative review, text analytics \\ https://doi.org/10.26813/001c.31627
}

Wine Business Journal

Vol. 5, Issue 1, 2022

\begin{abstract}
This study provides a systematic review of 76 relevant wine business studies published in the last 30 years. Our meta-analysis investigates six commonly used variables to explain wine innovation: absorptive capacity, technology adoption, sustainable practices, export orientation, firm size, and firm age. We also investigate the association between innovation and financial performance, using the reported effect sizes in the literature. Our meta-analysis reveals that absorptive capacity, technology adoption, sustainable practices, export orientation, and firm size positively correlate with innovation efforts, and innovation is positively associated with financial performance. However, we find no correlation between firm age and innovation. In addition to the meta-analysis, we apply basic text analytics and narrative review methodologies to identify a taxonomy of wine industry innovation according to four types of innovation. Based on our systematic literature review results, we make a series of managerial and policy recommendations for wine firms. Finally, we identify gaps in the literature and suggest future research directions.
\end{abstract}

\section{MANAGERIAL SUMMARY}

Measuring innovation in the wine industry is hard not only due to broad, abstract, and ambiguous connotations of the term "innovation" but also owing to peculiar characteristics of the wine industry, which complicate data collection, model building, and analysis. Moreover, innovation activities are often seen as business secrets, which considerably limits the exchange of information among fairms and with researchers, slowing down the diffusion of innovation within the wine industry. Despite these challenges, innovation may provide significant value to the industry; however, wine researchers need to convince practitioners that innovation may lead to competitive advantage and bring financial success. We believe that as both the quantity and quality of innovation-related wine research improves, the role that innovation plays in the wine industry would be clearer.

In this study, we provide a systematic review of the relevant wine business literature that consists of 76 studies published since 1991. While providing a narrative review of qualitative studies to identify common wine innovation types and forms, we perform a meta-analysis on the quantitative studies that report usable/convertible effect sizes for pairwise relationships between six commonly used variables (i.e., absorptive capacity, technology adoption, sustainable practices, export orientation, firm size, and firm age) and innovation, as well as the association between innovation and financial performance. Our analysis reveals that absorptive capacity, technology adoption, sustainable practices, export orientation, and firm size are positively correlated with innovation efforts, and innovation is positively associated with financial performance. Furthermore, we find that firm size moderates the relationship between absorptive capacity and innovation. We discuss several managerial and policy implications of our analysis and make a series of recommendations for future research avenues.

Our managerial recommendations include 1) engaging in innovative practices and collaborating with researchers, particularly in quantitative research projects, 2) prioritizing eco-innovation activities, 3) adopting emerging industry 4.0 technologies, 4) investing in absorptive capacity, and 5) increasing export-orientation and international visibility.

We suggest future quantitative studies to explore the impacts of 1) links to research institutions, 2) patent ownership, 3) and other variables, such as proximity, corporate social responsibility, national and international regulations, R\&D subsidies by governments, competitive pressures from stakeholders, and the managerial perceptions regarding innovation and financial performance. We also recommend researchers consider conducting MASEM, which currently does not exist in the literature. We recommend future qualitative research efforts to focus on clearly defining and classifying innovation in the wine sector and comparing the performances of wine supply chains before, during, and after the pandemic to exemplify how innovation has helped wine firms recover from disruptions caused by the pandemic. Finally, to mitigate the negative impacts of the recent pandemic on wine supply chains, we suggest that wine business research should benefit from interdisciplinary studies more, particularly with operations management and supply chain management fields. 


\section{INTRODUCTION}

Innovation is a broad and abstract term with multiple connotations. Innovation may simply mean a new idea, method, process, product, or technology. However, a key component of a general definition of innovation is that it must be implemented so that either a new product is made available to potential users or a new process is put into use in organizational operations (Gault, 2018). Organizational adoption of innovations is intended to increase organizational effectiveness or performance either in response to or as a preemptive action to changes in its internal or external environment (Damanpour, 1991). The pandemic drastically affected the global supply chain that serves wine and wine-related businesses in 2020. Yet, most wine businesses avoided major disruptions and learned that better planning is necessary during environmental uncertainty (Penn, 2021). Hence, introducing innovative methods, products, and services remains essential for wine business survival and success.

From a business perspective, innovation is a novel solution to a practical problem that generates financial and/or social value (Kavadias \& Ulrich, 2020). This definition emphasizes three essential features of business innovations:

- Innovations stem from practical needs.

- Innovations offer practical solutions.

- If successful, innovations provide some form of value to its stakeholders.

However, innovation is somewhat difficult to measure. Aside from its ambiguous connotations, innovation is also hard to assess due to its spill-over and synergistic amplification effects (i.e., the combined impact of distinct innovative practices in a firm might be larger than the sum of the individual effects of these innovative practices).

Management science literature usually breaks this broad concept into smaller parts to decrease abstraction and mitigate this measurement problem. Studies either treat innovation as a function-specific variable (i.e., production, logistics, marketing, and service innovation, etc.) (Faccin et al., 2017) or distinguish between process vs. product innovation (Murovec \& Prodan, 2008; Presenza et al., 2017; Utterback \& Abernathy, 1975), incremental vs. radical innovation (Ettlie et al., 1984), conventional vs. eco-innovation (Frigon et al., 2020), or internal vs. external innovation (Kavadias \& Ulrich, 2020).

Measuring innovation in the wine industry is more problematic than other industries due to peculiar characteristics of the wine industry, such as relatively high concentration of small and medium-sized enterprises (SME) (Lorenzo et al., 2018), widespread family ownership (Gilinsky et al., 2016), terroir-dependency of wine production (Van Leeuwen \& Seguin, 2006; Vaudour, 2002), orientation toward tradition (Vrontis et al., 2016), fragmented business and knowledge networks (Tyler et al., 2020), and reliance on tacit information (Woodfield \& Husted, 2017). These industry-specific characteristics complicate data collection, model building, and analysis. Furthermore, innovation activities are often seen as business secrets, which considerably limits the exchange of information among firms and with researchers, slowing down the diffusion of innovation within the industry.

This study provides a comprehensive review of research since 1991 that addresses wine business innovation, its forms, and its outcomes. In addition to basic text analytics and narrative review techniques, we conduct a meta-analysis of quantitative studies investigating the role of innovation in the wine industry. To the best of our knowledge, there is no meta-analysis on wine innovation. Therefore, our study aims to fill this gap in the literature. We believe that wine researchers and practitioners would greatly benefit from our systematic literature review, discussion on managerial and policy implications, and suggestions for future research.

The research questions that motivate our study are as follows: How strong is the link between innovation and financial performance in the context of the wine industry? What are the factors associated with and common forms of wine industry innovation? What research gaps and future research avenues exist in the wine innovation literature?

Our meta-analysis reveals a positive correlation between innovation and financial performance. Furthermore, we find positive associations between specific determinants (i.e., sustainable practices, technology adoption, absorptive capacity, firm size, and export orientation) and innovation. However, we find no correlation between firm age and innovation.

We organize the rest of the paper as follows. The following section (Section 2) discusses prominent theories that guide wine business research. The methods section (Section 3) summarizes our systematic study search procedure, provides descriptive statistics about the study pool, and introduces our meta-analytic approach. Section 4 provides the results of our meta-analysis and moderator analysis. Section 5 discusses managerial and policy implications, identifies gaps in the literature, and makes recommendations on potential future research efforts. Section 6 concludes the paper summarizing our findings and discusses limitations.

\section{THEORETICAL DISCUSSION}

This section discusses prominent theories that guide wine innovation: Resource- \& knowledge-based views and sustainability \& eco-innovation theories.

\section{Resource and Knowledge-Based Views}

The resource-based view (RBV), the leading theory used to explain wine innovation, argues that competitiveness and financial success are primarily determined by firms' internal resources (Barney, 1991). These internal resources include quality of HR (i.e., formal education, skills, and training), technological capabilities, financial assets, and R\&D activities (Cohen \& Levinthal, 1990; Galbreath, 2005). Firms gain a competitive advantage by managing and strategically investing in these endogenous capabilities. For instance, firms may include sustainable practices that lead to operational efficiencies to improve their performance (Barney, 1999). Furthermore, Atkin \& Johnson (2010) show that forming alliances for marketing purposes could be an effective strategy to gain a competitive advantage. A fundamental assumption in RBV is that as the firm size increases, 
innovation capacity increases. Therefore, large firms are considered more advantageous than small and medium sized enterprises (SMEs) due to their extensive pool of highquality HR, substantial financial assets, and sizable technological infrastructure.

Some studies challenge the classical RBV by providing a different perspective. For instance, Humphreys \& Carpenter (2018) point out that some large and established marketdriving wine firms achieve competitive advantage by playing a status game rather than strategically investing in their endogenous resources and innovative practices. Contrary to market-driven firms that rely on consumer information as a key input to develop innovative strategies and techniques, status-driven (market driving) firms seek to shape consumer preferences by creating a vision, employing celebrity winemakers, influencing critics and media, and affecting retail sales by promoting scores by critics and form alliances to maintain and enhance their status (Humphreys \& Carpenter, 2018). One may argue that playing a status game itself may require significant resources, so the argument does not refute RBV but intends to clearly distinguish how resources are utilized to gain competitive advantage by status- and market-driven firms. This debate is still an open question.

Knowledge-based view (KBV), a derivation of RBV, considers knowledge as the most crucial asset of a firm that pursues a competitive advantage via innovation (Grant, 2015; Woodfield \& Husted, 2017). This theory argues that knowledge base $(\mathrm{KB})$ is a function of technical expertise, education level, HR training, technological capabilities, and $R \& D$ efforts. The central assumption is that the larger the $\mathrm{KB}$, the more likely the innovation is. Recent knowledgebased studies find that innovation does not diffuse evenly on a par with proximity; instead, it spreads in a highly selective manner in proportion to the size of knowledge bases (KB) of heterogeneous firms. Firms with distinct KBs make up knowledge networks (KN). KN differs from a business network (BN) because the former is established selectively considering the relative capacities of firms, whereas the latter represents a pervasive structure that brings nearby firms that operate in the same sector together where hierarchy is less important. Giuliani (2007) finds that the structure of KNs significantly differs from that of BNs such that diffusion of innovation is more uneven in the former, and firms with stronger KBs are more likely to be central in the KN.

Some studies examine the impact of the inter-generational exchange of tacit information on innovative capacity. For instance, Woodfield \& Husted (2017) find that bi-directional exchange of information between generations in family firms is critical for innovation. They state that transferring the incumbent's experience-based tacit knowledge to the successor is necessary but not sufficient for maintaining and improving innovative capacity. The successor should also share up-to-date information gained via education with the incumbent. Finally, within this stream of research, the roles that academic institutions play in wine-related innovation via firm-university linkages has attracted some attention, but results are quite country-dependent. For example, Giuliani \& Arza (2009) find that in Chile, the stronger the firms' $\mathrm{KB}$ and higher the university's scientific quality, the more likely a university-industry linkage is.
However, in Italy, the results are almost reversed. In both Chile and Italy, the stronger the KBs of firms with connections to universities, the higher the diffusion of innovation (Giuliani \& Arza, 2009).

\section{Sustainability and Eco-Innovation Theories}

In broadest terms, sustainability is the ability of a firm to use its resources without harming the ecological system in meeting the wants and needs of customers. Sustainability theory (ST), which has emerged in reaction to the classical myopic profit-maximizing firm behavior, argues that firms should be farsighted in distributing resources more equitably between generations to enable sustainable development. Harsh economic competition leads to the accelerated use of non-renewable energy sources, which changes the climate, negatively affecting agricultural practices, including wine production.

Rooted mainly in ST, eco-innovation theory (EIT) asserts that firms should care about the long-lasting impacts of innovations on our biosphere and future generations. Due to its close relationship with the terroir, the wine industry is one of the sectors that eco-innovation has a significant value potential. As defined by Kemp \& Pearson (2007), ecoinnovation is "the production, assimilation or exploitation of a product, production process, service or management or business method that is novel to the organization (developing or adopting it) and which results, throughout its life cycle, in a reduction of environmental risk, pollution and other negative impacts of resource use (including energy use) compared to relevant alternatives.” As scientific studies in environmental sciences, earth and planetary sciences, agriculture, biology, chemistry, and material sciences point out, the earth system and its constituent subsystems are governed by complex and dynamic interactions between biological systems, materials, and energy. The prolonged coexistence of our biosphere and civilizations requires social, environmental, and economic sustainability. Various endogenous and exogenous factors affect the ecological behavior of a firm.

The roles that integrated environmental management systems (EMS) play in improving firm outcomes, sustainable practices, and eco-innovations have attracted some attention in the EIT literature. For instance, Sroufe (2009) demonstrates that the EMS positively impacts specific operational performance metrics, such as quality, reduced cost, and international sales. Atkin et al. (2012) find that wine firms with a clear EMS exhibit significantly different cost leadership and differentiation strategies. They state that wineries with a clear EMS are more likely to increase their sustainability commitments, enter new markets, and operate more efficiently than those without a clear EMS. Melnyk et al. (2003) point out that firm age, size, and ownership type are related to investments in EMS. Gilinsky et al. (2008) indicate a propensity to invest in EMS innovations by young entrepreneurial agricultural businesses. 


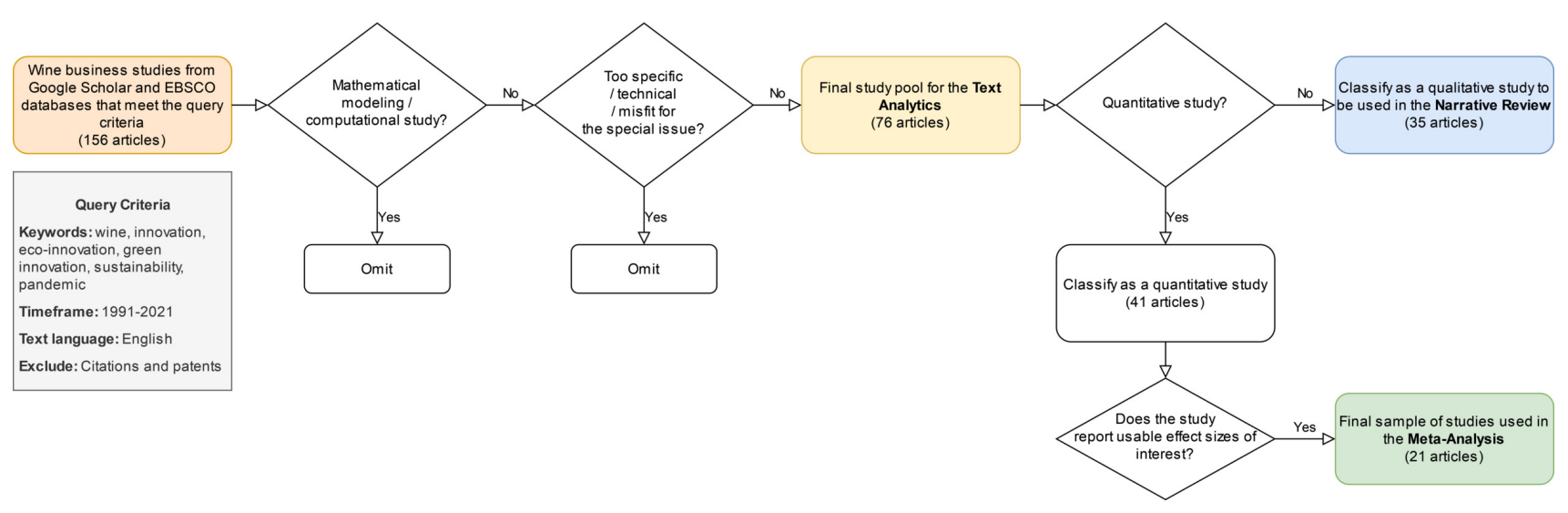

Figure 1. Systematic Review Procedure

\section{METHODS}

\section{Search Procedure, Inclusion Criteria, and Final Sample of Studies}

Figure 1 illustrates our systematic review procedure. We first conduct a search for studies published in English since 1991 that contain combinations of "wine," "innovation," "eco-innovation," "green innovation," "sustainability,” and "pandemic" in the title, abstract, and the article text on Google Scholar and EBSCO databases, excluding citations and patents. This initial search yields 156 candidate studies. Although the wine business literature is quite vast, studies that focus on innovation is quite limited because of the peculiar characteristics of the wine industry, as discussed in the Introduction section. We perform an initial screening to exclude 1) computational studies that use mathematical modeling techniques, such as optimal scheduling of wine bottling operations, and 2) studies that are too specific or technical, such as studies that measure the impact of a specific microbiological ingredient on wine quality. While screening the candidate studies, we also check if a study fits well to the scope of the special issue. After this meticulous examination process, we identify the most relevant 76 wine business studies as our study pool.

We first perform preliminary text analytics on all 76 articles to provide insight into the last 30 years' research efforts on wine innovation. We then classify this study pool based on five criteria: theory, methodology, independent variable(s), dependent variable(s), and major contribution. This classification helps us categorize studies as either quantitative or qualitative and identify research gaps. We classify 35 articles as qualitative and 41 studies as quantitative. We use qualitative studies to perform a narrative review to identify common wine innovation types and forms addressed in the literature. Quantitative studies that report usable/convertible effect sizes of interest are used in the meta-analysis. Out of 41 quantitative studies, only 21 studies report usable/convertible effect sizes.

\section{Overview of the Study Pool}

We provide the detailed classification of the quantitative and qualitative articles in the study pool in Tables A2 and A3 in the Appendix, respectively. To save space, we use

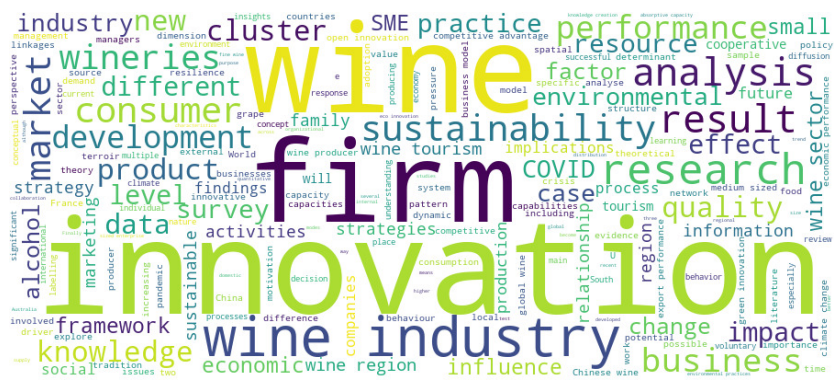

Figure 3. Word Cloud of the Study Pool

some abbreviations, the list of which is also presented in the Appendix (see Table A1). To give the reader a flavor of our study pool, we provide descriptive statistics using the bar and pie charts in Figure 2 .

The bar charts illustrate the frequency of studies by country and by period. As can be seen, Italy, the USA, Spain, Canada, Australia, and France are relatively better represented than other countries, and the number of relevant wine studies increases over time (i.e., the majority of wine studies published between 2013-2020). There are more quantitative studies in the study pool than qualitative studies (53.9\% opposed to $46.1 \%$ ). The prominent theories that provide bases to these studies are resource-based view (RBV), knowledge-based view (KBV), sustainability theory (ST), eco-innovation theory (EIT), and geographical proximity theory (GPT). The most frequently applied quantitative methodologies are exploratory data analysis (EDA), followed by principal component analysis (PCA), ordinary least squares (OLS) regression, cluster analysis, logistic regression. Widely adopted qualitative research methodologies are surveys, interviews, reviews, and case studies.

\section{Text Analytics}

Figure 3 depicts a word cloud of the study pool. The word cloud attaches higher importance to high-frequency words in the text, representing them bigger and bolder than less important ones.

Figure 4 summarizes basic text analytics conducted on the titles, abstracts, keywords, and main bodies of all study 


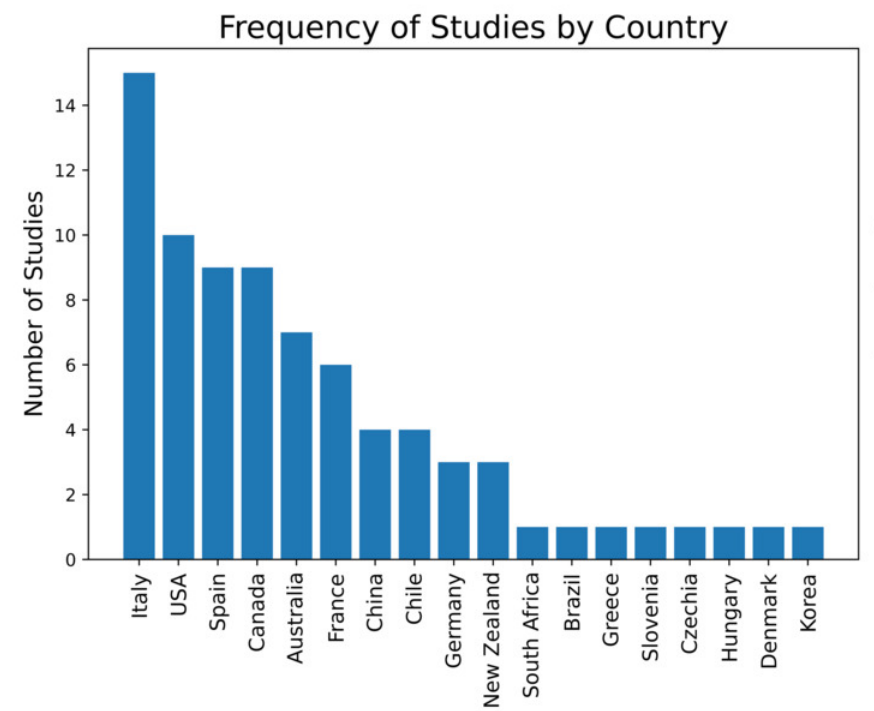

Quantitative vs. Qualitative Studies

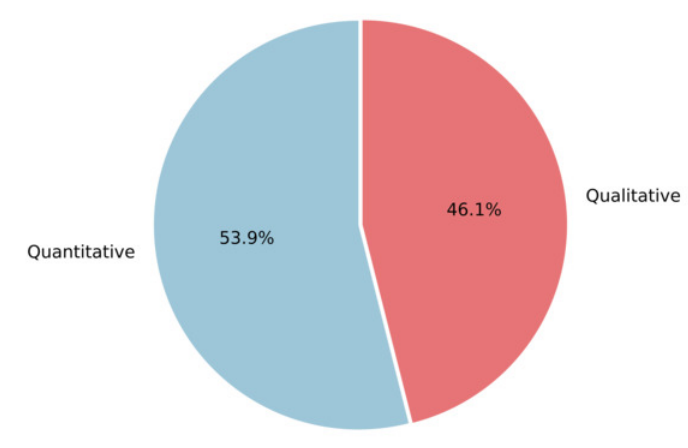

Quantitative Methodologies

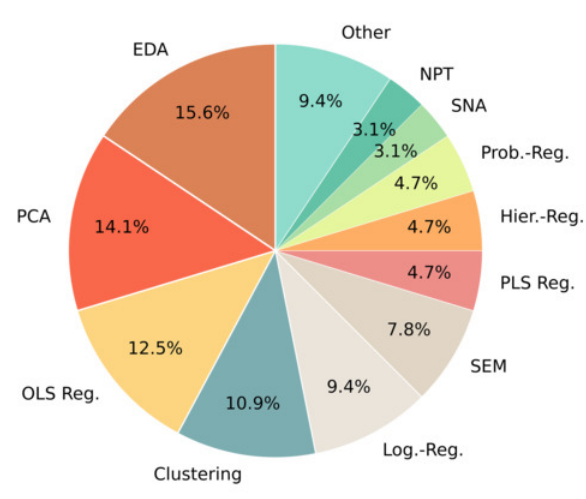

Figure 2. Descriptive Statistics about the Study Pool

pool articles. The left figure (Figure 4a) illustrates the frequencies of innovation types categorized by quantitative and qualitative articles. As can be seen, the most frequently discussed innovation type is green or eco-innovation, followed by product, marketing, process, conventional, and logistics/delivery innovations. Another interesting finding is that quantitative studies more frequently mention innovation than qualitative studies in all categories. The right fig-
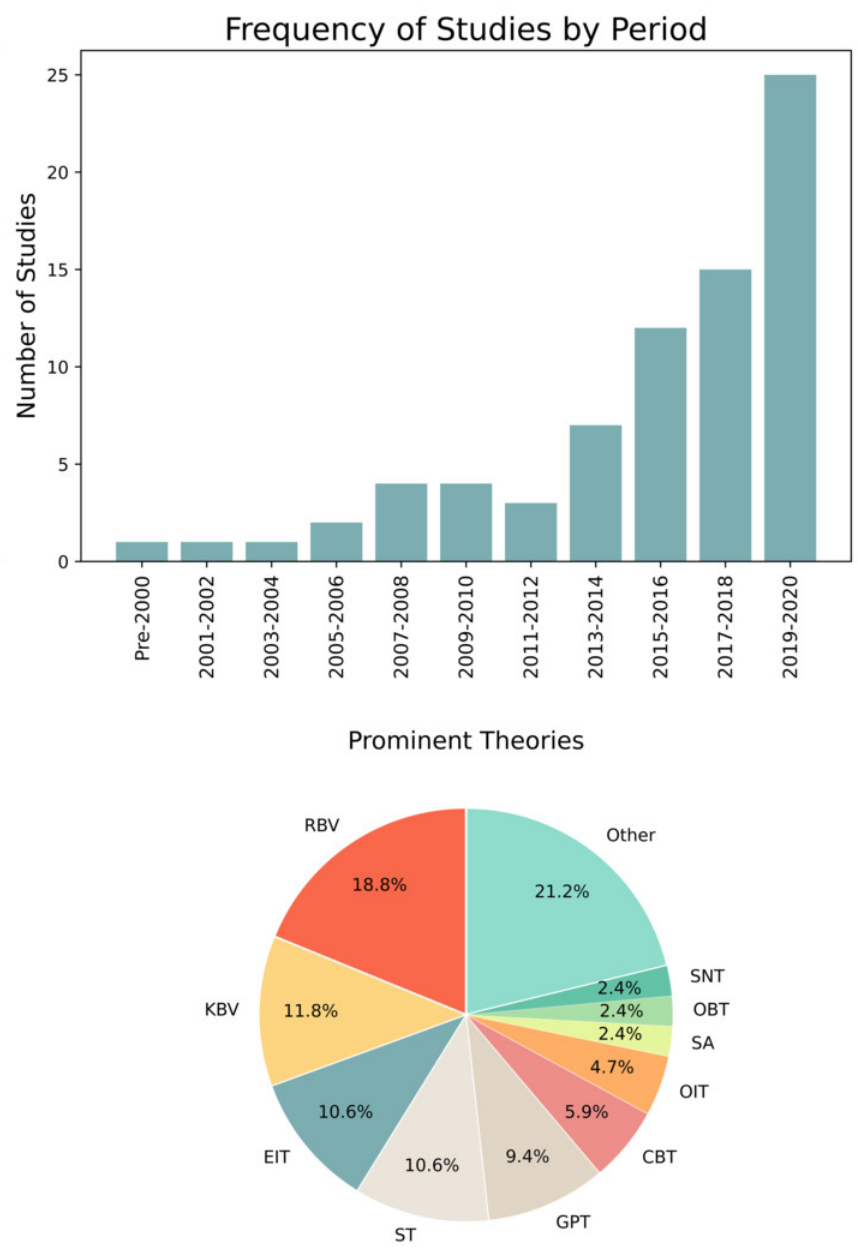

Qualitative Methodologies

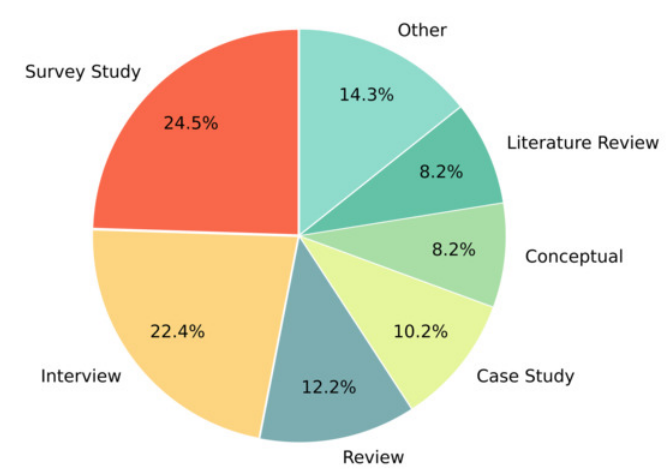

ure (Figure $4 \mathrm{~b}$ ) depicts the frequencies of most repeated keywords by study type. The keyword "wine" has the highest frequency (as expected), followed by "sustainability," "innovation," "information," and "performance." Some of these keywords, such as "wine," "family," “COVID-19”, "terroir," and "tacit," are used more often in qualitative studies than quantitative studies. These findings are consistent with a recent bibliometric review of $213 \mathrm{Web}$ of Science wine 

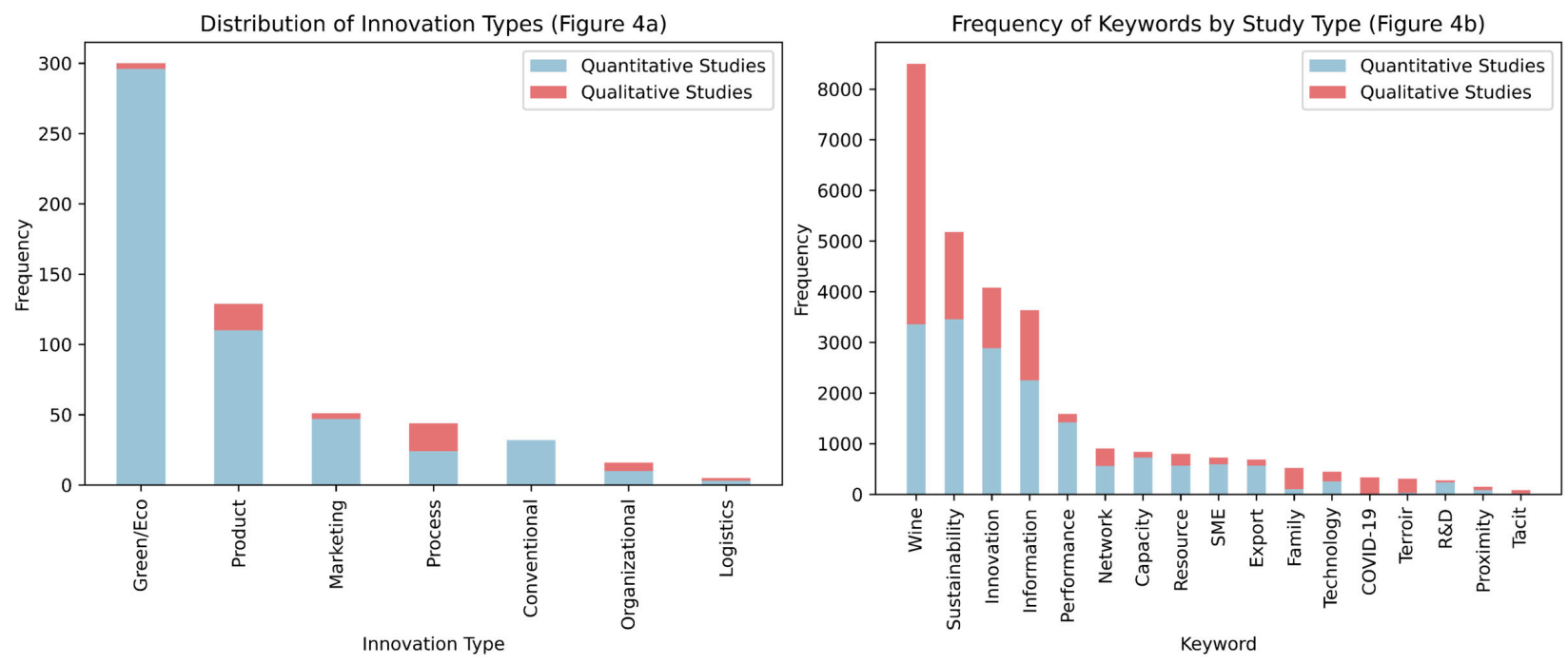

Figure 4. Summary of Basic Text Analysis

innovation articles by Porto-Gómez et al. (2020). The researchers' review assessed the topics discussed and discovered that non-technological innovation is the most researched topic, while product innovation is focused primarily on consumer demand for wine; sustainability and sustainable innovation are both gaining relevance.

\section{Narrative Review}

Using NVivo software, we classify common forms of innovation in the qualitative studies according to the four types of innovation described by Gault (2018, p. 619): product innovation, production or delivery innovation, organizational innovation, and marketing/communication innovation. The narrative review approach is designed for topics that hinder a full systematic review (Snyder, 2019) and may provide valuable insights (Baumeister \& Leary, 1997). We summarize the results in Table 1.

We limit our coding of the forms to only those papers that had used wine business data in their analyses. Production or delivery innovation is the most common type of innovation (mentioned $76 \%$ of the articles), followed by product innovation (70\%), marketing/communication innovation (40\%), and organizational innovation (26\%).

\section{Meta-Analysis}

After this broad summary, we turn to our meta-analysis, which uses a subset of quantitative studies (21 out of 41 articles) that report usable/convertible effects sizes (60 effect sizes in total). Developed by Hunter et al. (1981), the metaanalytic approach is a high level, systematic, and replicable methodology that synthesizes many quantitative empirical studies in a scientific field to draw broad statistical conclusions about the magnitude and direction of relationships between variables of interest (Hunter \& Schmidt, 1990, 2000, 2004). This study uses two R packages (metafor and robumeta) to conduct the meta-analysis illustrated in Figure 5 .
Following the meta-analysis methodology, we investigate a single relationship at a time. Since the wine studies are drawn from different populations with substantial heterogeneity, we use random-effects models, which assign less weight to larger studies with smaller variance (Quintana, 2015). Heterogeneity refers to the between-study variation (high heterogeneity requires a random effect model). We report $I^{2}$ statistic as the measure of heterogeneity. $I^{2}$ is a performance statistic that indicates the percentage of variance attributable to study heterogeneity rather than chance. Unlike the Q-statistic, $I^{2}$ is not sensitive to the number of studies included in the analysis (Quintana, 2015). We select Pearson correlation coefficient $(r)$ as the primary effect size since it is a standard metric reported in most studies in our study pool and is relatively easier to interpret than other metrics. If a study does not report $r$ but reports another convertible effect size (i.e., F-statistic, tstatistic, odds ratio, partial eta squared, and Kendall's tau), we transform them into Pearson correlation coefficients $(\mathrm{Hu}$ \& Yang, 2021; Lipsey \& Wilson, 2001; Peterson \& Brown, 2005; Walker, 2003) using the formula provided in the Appendix (Table A4 and Figure A2). Finally, we perform a moderator analysis using firm size (average number of employees), firm age (average firm age in years), geography (whether a sample belongs to an old world or new world country), and publication quality (whether a study is published in a $1^{\text {st }}$ Tier or $2^{\text {nd }}$ Tier outlet) as the moderator variables.

\section{Variable Definitions and Measurement}

In this subsection, we define the variables in Figure 5 and exemplify how they are measured. It is important to note that there are variables that we could not include in our analysis due to insufficient number of studies, such as proximity, corporate social responsibility, government subsidies and tax cuts, national and international regulations, competitive pressures, and perceptions of managers. Although some of these measures are well studied in other industries, 
Table 1. Wine Business Innovation Types and Forms

\begin{tabular}{|c|c|c|}
\hline Product Innovation & Production or Delivery Innovation & Organizational Innovation \\
\hline $\begin{array}{l}\text { New or significantly } \\
\text { improved product or } \\
\text { service }\end{array}$ & $\begin{array}{l}\text { New or improved raw materials, production } \\
\text { techniques, equipment, technology, grape growing and } \\
\text { transformation techniques, and logistics }\end{array}$ & $\begin{array}{l}\text { New or significantly improved methods } \\
\text { in business practices, workplace } \\
\text { organization, or external relations }\end{array}$ \\
\hline $\begin{array}{l}\text { Product and brand } \\
\text { differentiation }\end{array}$ & Patent new technologies & New business or management strategy \\
\hline Change in components & Use of organic, chemical, and innovative substances & New human resources policies \\
\hline $\begin{array}{l}\text { Change in product } \\
\text { design }\end{array}$ & Reduction of material, water, and energy use & $\begin{array}{l}\text { New manufacturing management } \\
\text { system }\end{array}$ \\
\hline $\begin{array}{l}\text { Sales of hotter climate } \\
\text { varieties }\end{array}$ & Use materials with less greenhouse gas-intensive & Quality control \\
\hline $\begin{array}{l}\text { New wine container } \\
\text { closures }\end{array}$ & Recycle waste, water, materials & $\begin{array}{l}\text { Simplification of the decision-making } \\
\text { process }\end{array}$ \\
\hline $\begin{array}{l}\text { Types of wine produced, } \\
\text { new varietals }\end{array}$ & Alternative energy use, packaging, and waste disposal & New forms of human resources training \\
\hline $\begin{array}{l}\text { New wines responsive } \\
\text { to consumer trends }\end{array}$ & Reduction of refrigeration loads & $\begin{array}{l}\text { New organizational philosophies, } \\
\text { culture, or organizational structure }\end{array}$ \\
\hline $\begin{array}{l}\text { Organic products/ } \\
\text { farming }\end{array}$ & Energy-efficient technology & New competitor connections \\
\hline $\begin{array}{l}\text { New product } \\
\text { development through } \\
\text { Ol, product } \\
\text { development speed }\end{array}$ & $\begin{array}{l}\text { Grow grapes suitable for hot temperatures, establish } \\
\text { vineyards in areas less subject to climate risk }\end{array}$ & $\begin{array}{l}\text { Next-generation organizational policies, } \\
\text { practices, mechanisms, and structures }\end{array}$ \\
\hline New tasting room & Canopy management techniques & Marketing/Communication Innovation \\
\hline $\begin{array}{l}\text { Entry-level trendy } \\
\text { wines }\end{array}$ & New distribution through open innovation & $\begin{array}{l}\text { New marketing tools (QR code, website, } \\
\text { newsletter, wine club, training course) }\end{array}$ \\
\hline $\begin{array}{l}\text { Educate young } \\
\text { consumers' palates } \\
\text { through events }\end{array}$ & Warehousing and breeding innovation & Strengthen brand \\
\hline Increased quality & Organic certification & $\begin{array}{l}\text { New or significantly improved marketing } \\
\text { methods }\end{array}$ \\
\hline $\begin{array}{l}\text { Design new products } \\
\text { with new technologies }\end{array}$ & Wildlife protection & $\begin{array}{l}\text { New promotion/sales through open } \\
\text { innovation }\end{array}$ \\
\hline $\begin{array}{l}\text { Enhance existing } \\
\text { products with new } \\
\text { technology }\end{array}$ & $\begin{array}{l}\text { Improved value chain activities (i.e., changing buying } \\
\text { practices, sale of wine by-products, and technical } \\
\text { advice/support from peers) }\end{array}$ & $\begin{array}{l}\text { Enter new markets, new market } \\
\text { segment }\end{array}$ \\
\hline New packaging/labels & Monitoring wine quality with biosensors & Raise wine status \\
\hline $\begin{array}{l}\text { New bundles of } \\
\text { products and services }\end{array}$ & Heated and refrigerated maceration & Market carbon policy \\
\hline $\begin{array}{l}\text { New box containers for } \\
\text { high-end wines }\end{array}$ & Photovoltaic roofing & Wine selling innovation \\
\hline $\begin{array}{l}\text { A large range of wines } \\
\text { offered }\end{array}$ & Biotechnologies applied to yeasts & Family promotes wines \\
\hline $\begin{array}{l}\text { Niche products based } \\
\text { on typical or organic } \\
\text { products }\end{array}$ & Submerged cover fermentation & $\begin{array}{l}\text { Use of social media to promote wine } \\
\text { products }\end{array}$ \\
\hline
\end{tabular}

their impacts on wine innovation and financial performance have attracted relatively less attention.

Innovation. As mentioned earlier, studies either use "innovation" as a generic term or use different innovation classifications (i.e., product vs. process innovation and conventional vs. eco-innovation). To ensure consistency and prevent over-representation of a single study in the metaanalysis, we use only one effect size per study for each relationship pair. For instance, if a study reports multiple effect sizes coming from the same sample, each corresponding to a specific class of innovation (i.e., product vs. process in- novation or green vs. conventional innovation), we use the effect sizes that correspond to "product innovation" and "green/eco-innovation", respectively, since green/eco- and product innovations are the most frequently mentioned innovation categories in the study pool (Figure 4). The only exception is a study by Giuliani \& Arza (2009), who report two sets of effect sizes coming from two distinct wine clusters, Italy and Chile, respectively.

Financial performance. Financial performance is a continuous measure that indicates how successfully and efficiently a firm utilizes its resources to maximize its revenue. 


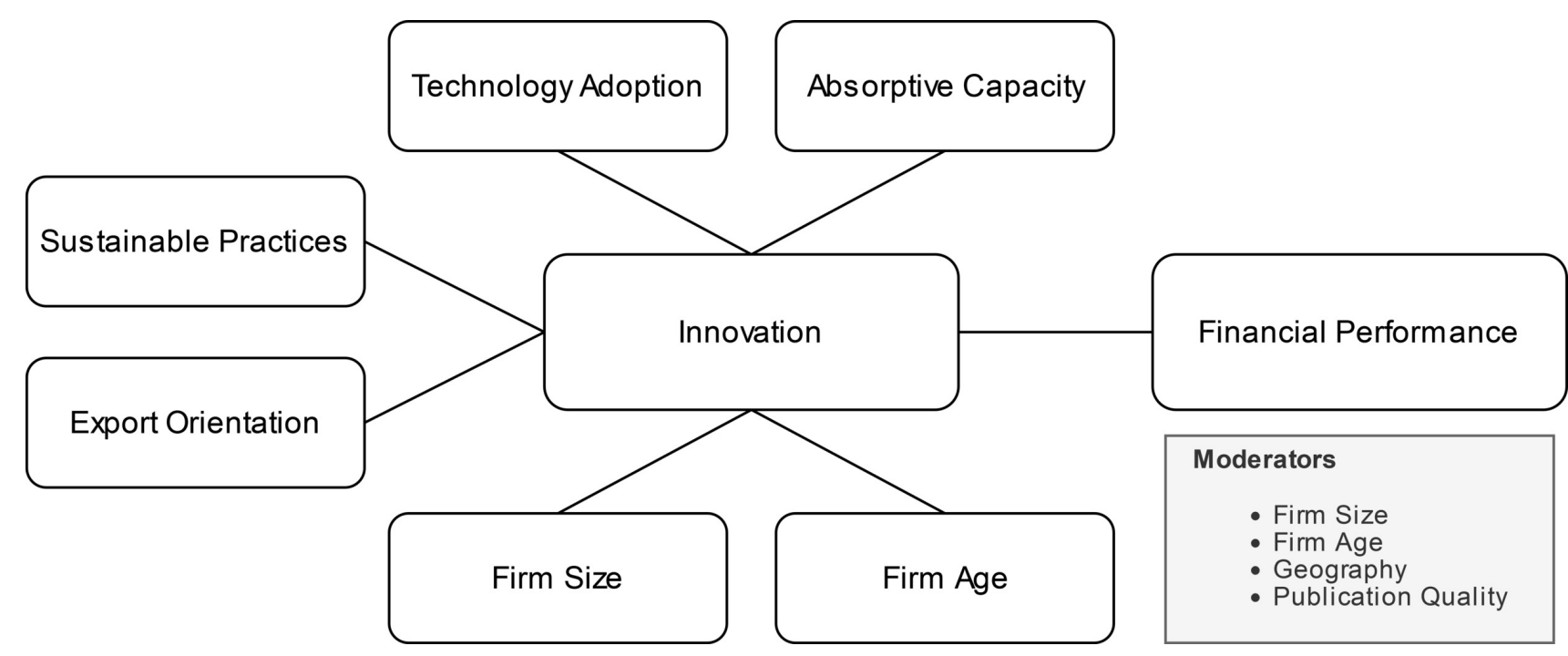

Figure 5. Meta-Analysis Framework

Common metrics to measure financial performance include the volume of wine sales (Galbreath et al., 2016), profit (Lorenzo et al., 2018), market share (Guerrero-Villegas et al., 2018), return on assets (Pradana et al., 2020), subjective evaluation of last 5-year's financial performance in comparison to similar firms (Knight et al., 2019), and cost-reduction as a result of employing an innovation (Annunziata et al., 2018).

Absorptive capacity. Absorptive capacity is the ability of a firm to embrace, assimilate, and apply new knowledge for commercial ends (Cohen \& Levinthal, 1990). R\&D efforts and/or expenditures (Stasi et al., 2016), quality of HR (Giuliani \& Arza, 2009; Giuliani \& Bell, 2005), patent ownership (Ahn et al., 2013), knowledge acquisition and assimilation efforts (Pradana et al., 2020), and relationships with external knowledge sources, such as universities (Presenza et al., 2017) are often used to measure absorptive capacity. For instance, Giuliani \& Arza (2009) measure absorptive capacity (knowledge base) as a function (weighted average) of three distinct variables: formal training of HR (a continuous variable calculated using a weighted average formula), HR national and international experience in months (a continuous variable calculated using another weighted average formula), and experimentation effort (a categorical variable measured from 0 to 4 ).

Technology adoption. Adopting technologies, such as wine machinery, biotechnologies, biosensors, and other wine-making techniques, are considered good predictors of innovation (Stasi et al., 2016). Though falling behind other sectors, automation in the wine industry has gained traction in the last decade with advancements in AI, robotics, sensor, and other Industry 4.0 technologies. Technology adoption is often measured via survey questions on whether a firm adopts a particular technology or not, so it is often treated as a binary or a categorical variable (Annunziata et al., 2018).

Sustainable practices. Common sustainable practices are organizational policies (i.e., environmental policy statement, environmental purchasing policy, etc.), procedures (i.e., collecting data related to ecological issues, supplier se- lection based on environmental criteria, engaging in environmental audits, etc.), strategies (i.e., eco-labeling, promoting eco-certification, strategic goals for reducing waste and carbon emissions, etc.), and other environmental applications, such as environmental management system, restoring contaminated soil, using recycled material (Guerrero-Villegas et al., 2018), monitoring emissions (Galbreath et al., 2016), use of frugal irrigation systems (Fiore et al., 2017), environmental disclosure (Knight et al., 2019), and using renewable sources of energy (Annunziata et al., 2018). Sustainable practices are typically measured via surveys and are often treated as a categorical variable.

Export orientation. Export orientation is a continuous measure to identify a firm's primary growth strategy, usually reflected as a ratio of exports to total sales (exports + domestic sales) (Maurel, 2009). The larger the sales are to other countries, the higher the export orientation is (Annunziata et al., 2018).

Firm size. Firm size is typically measured either by the $\log$ number of employees (Annunziata et al., 2018), the amount of wine production (Galbreath et al., 2016), total sales, or total assets (Guerrero-Villegas et al., 2018).

Firm age. Firm age measures the cumulative time in years since the firm was founded. Most studies use the log firm age to mitigate considerable variation in firm ages.

Moderator Variables. We examine four moderator variables: firm size, firm age, geography, and publication quality. To measure firm size, we use the average number of employees reported by these studies. To account for inherent variation in firm sizes and ages, we take the log of these measures (if not already taken). Geography and publication quality are categorical variables. To investigate the impact of geography, we classify studies as either "New World" or "Old World" studies. We also group each study as either $1^{\text {st }}$ or $2^{\text {nd }}$ Tier. We primarily use the ABDC Journal Quality List for this classification. If an academic journal is not listed in the ABDC Journal Quality List, we turn to other lists and global metrics, such as Harzing - ABS 2021, JCR 2021, and h5-index. Journals that are rated $A^{-}$and above 
Table 2. Summary of Meta-Analysis Results

\begin{tabular}{l|c|ccccc}
\hline Relationship & $\overline{\mathbf{r}}$ & $\mathbf{9 5 \%} \mathrm{Cl}$ & $\mathbf{k}$ & $\mathbf{N}$ & $\mathbf{I}^{2}$ & $\mathbf{p}$-val. \\
\hline Sustainable Practices <-> Innovation & 0.54 & {$[0.13,0.80]$} & 8 & 2,000 & $99 \%$ & 0.013 \\
Technology Adoption <-> Innovation & 0.34 & {$[0.15,0.51]$} & 4 & 1,181 & $92 \%$ & 0.001 \\
Absorptive Capacity <-> Innovation & 0.29 & {$[0.19,0.39]$} & 14 & 2,450 & $86 \%$ & 0.000 \\
Absorptive Capacity (Adj.) <-> Innovation & 0.28 & {$[0.12,0.44]$} & 14 & 2,450 & $84 \%$ & 0.001 \\
Firm Size <-> Innovation & 0.14 & {$[0.05,0.23]$} & 8 & 1,273 & $57 \%$ & 0.002 \\
Export Orientation <-> Innovation & 0.11 & {$[0.02,0.20]$} & 7 & 1,544 & $93 \%$ & 0.023 \\
Firm Age <-> Innovation & 0.02 & {$[-0.08,0.11]$} & 6 & 1,839 & $67 \%$ & 0.685 \\
Firm Age (Adj.) <-> Innovation & 0.06 & {$[-0.10,0.22]$} & 6 & 1,839 & $70 \%$ & 0.467 \\
\hline Relationship with Financial Performance & $\overline{\mathbf{r}}$ & $95 \% \mathrm{Cl}$ & $\mathbf{k}$ & $\mathbf{N}$ & $\mathbf{I}^{2}$ & $\mathbf{p}-\mathrm{val}$. \\
\hline Innovation <-> Financial Performance & 0.27 & {$[0.16,0.38]$} & 9 & 2,778 & $88 \%$ & 0.0001 \\
\hline
\end{tabular}

$\overline{\mathbf{r}}$ : Estimated average effect size, $\mathbf{k}$ : Number of studies, $\mathbf{N}$ : Total sample size, Adj.: Adjusted

(i.e., $A^{-}, A, A^{+}$) are classified as $1^{\text {st }}$ Tier, whereas journals rated below $A^{-}(i . e ., B, C, D)$ are classified as $2^{\text {nd }}$ Tier.

\section{RESULTS}

Table 2 summarizes meta-analysis results (please see Figure A1 in the Appendix for the individual forest plots). We use funnel plots, Egger's regression, and rank tests to assess potential publication bias (please see Table A5 and Figure A3 in the Appendix). Results indicate small publication biases related to group of studies corresponding to 1) absorptive capacity and innovation, and 2) firm age and innovation. After adjusting for publication bias using the Vevea and Hedges weight-function model, our initial estimate for the relationship between absorptive capacity and innovation $(\bar{r}=0.29, p<0.0001)$ decreases to $(\bar{r}=0.28$, $p<0.0010)$, whereas the initial estimate for the correlation between firm age and innovation $(\bar{r}=0.02, p<0.6845)$ increases to $(\bar{r}=0.06, p<0.4670)$. However, even after the adjustment, the correlation between firm age and innovation remains insignificant.

All $I^{2}$ values indicate substantial heterogeneity. When we compare estimated average effect sizes $(\bar{r})$, sustainable practices $(\bar{r}=0.54, \quad p<0.0133)$, technology adoption $(\bar{r}=0.34, \quad p<0.0005), \quad$ absorptive capacity $(\bar{r}=0.28$, $p<0.0010)$, firm size $(\bar{r}=0.14, p<0.0016)$, and export orientation $(\bar{r}=0.11, p<0.0225)$, appear to have relatively the largest and statistically significant effects on innovation.

The relatively large correlation between sustainable practices and innovation is meaningful as most studies in our study pool focus on green innovation (Figure 4). Some of these studies find significant associations between the two variables (see the corresponding forest plot). Furthermore, in practice, green/eco-innovations constitute a relatively large segment of innovations implemented by wine firms due to the close ties of winemaking to terroir. The large positive association between technology adoption and innovation is intuitive since implementing innovative practices often requires new technologies, and technology adoption typically speeds up the existing innovations. The medium positive correlation between absorptive capacity and innovation emphasizes the importance of yet another duality: on the one hand, increased absorptive capacity may create a more conducive atmosphere for innovations to take place; on the other, innovative practices may lead to increased absorptive capacity by attracting highly skilled labor, granting new patents, and expanding existing R\&D activity. The medium positive association between firm size and innovation is intuitive due to the inherent correlation between firm size and absorptive capacity (please see the moderator analysis). Finally, the small positive association between export orientation and innovation highlights the link between external openness and innovative practices.

The analysis also reveals a significant positive association between innovation and financial performance $(\bar{r}=0.27, p<0.0001)$. This finding is important since it justifies that the individual positive associations previously identified by each of the nine studies in the analysis collectively point out a significant positive correlation between innovation and financial performance. This result has two implications. First, wine firms that achieve higher financial performance may be more likely to engage in innovative practices. Second, successful innovative practices may translate into financial success. We find no correlation between firm age and innovation. One explanation could be that established wine firms usually have larger resources to innovate; however, they may be more tradition-oriented, whereas younger firms may be more innovation-driven despite lacking the necessary resources to innovate.

Finally, we also investigate the relationship between links to research institutions and innovation. Conventional wisdom suggests that the stronger the links to research institutions, the more likely the innovation is. However, when we conduct a meta-analysis on this relationship using the existing studies, we find a small correlation $(\bar{r}=0.05, p<0.27)$, which is not statistically significant. Furthermore, the corresponding $I^{2}$ value is $0 \%$, indicating no heterogeneity. This is because of the small number of studies with effect sizes located close to zero (please see the corresponding forest plot). Therefore, we exclude this measure from the analysis. 
Table 3. Summary of Moderator Analysis Results

\begin{tabular}{|c|c|c|c|c|c|c|}
\hline \multicolumn{2}{|c|}{ Innovation \& Financial Performance } & \multirow{2}{*}{$\frac{\text { Estimate }}{0.03}$} & \multirow{2}{*}{$\begin{array}{c}\text { SE } \\
0.13\end{array}$} & \multirow{2}{*}{$\frac{\text { z-value }}{0.21}$} & \multirow{2}{*}{$\frac{p \text {-value }}{0.84}$} & \multirow{2}{*}{$\frac{95 \% \mathrm{Cl}}{[-0.23,0.29]}$} \\
\hline Geography & New vs. Old World & & & & & \\
\hline Publication Quality & 1st Tier vs. 2nd Tier & -0.12 & 0.12 & -1.04 & 0.30 & {$[-0.36,0.11]$} \\
\hline \multicolumn{7}{|c|}{ Absorptive Capacity \& Innovation } \\
\hline Firm Size & Sample mean & $0.20^{*}$ & 0.08 & 2.52 & 0.01 & {$[0.045,0.36]$} \\
\hline Firm Age & Sample mean & 0.08 & 0.12 & 0.66 & 0.51 & {$[-0.15,0.31]$} \\
\hline Geography & New vs. Old World & -0.10 & 0.12 & -0.80 & 0.43 & {$[-0.34,0.14]$} \\
\hline Publication Quality & 1st Tier vs. 2nd Tier & -0.18 & 0.12 & -1.58 & 0.11 & {$[-0.41,0.04]$} \\
\hline \multicolumn{7}{|c|}{ Technology Adoption \& Innovation } \\
\hline Geography & New vs. Old World & -0.01 & 0.29 & -0.03 & 0.98 & {$[-0.58,0.56]$} \\
\hline Publication Quality & 1st Tier vs. 2nd Tier & -0.11 & 0.24 & -0.45 & 0.65 & {$[-0.58,0.36]$} \\
\hline \multicolumn{7}{|c|}{ Sustainable Practices \& Innovation } \\
\hline Firm Size & Sample mean & 0.27 & 0.17 & 1.59 & 0.11 & {$[-0.06,0.60]$} \\
\hline Firm Age & Sample mean & 0.25 & 0.28 & 0.90 & 0.37 & {$[-0.29,0.79]$} \\
\hline Geography & New vs. Old World & 0.30 & 0.53 & 0.55 & 0.58 & {$[-0.75,1.34]$} \\
\hline Publication Quality & 1st Tier vs. 2nd Tier & 0.50 & 0.51 & 1.00 & 0.32 & {$[-0.49,1.50]$} \\
\hline \multicolumn{7}{|c|}{ Export Orientation \& Innovation } \\
\hline Firm Size & Sample mean & $0.01^{*}$ & 0.00 & 2.06 & 0.04 & {$[0.00,0.02]$} \\
\hline Firm Age & Sample mean & 0.00 & 0.68 & -0.01 & 0.99 & {$[-0.35,0.33]$} \\
\hline Geography & New vs. Old World & 0.10 & 0.14 & 0.76 & 0.45 & {$[-0.16,0.37]$} \\
\hline Publication Quality & 1st Tier vs. 2nd Tier & 0.01 & 0.10 & 0.11 & 0.91 & {$[-0.19,0.21]$} \\
\hline \multicolumn{7}{|l|}{ Firm Size \& Innovation } \\
\hline Geography & New vs. Old World & -0.03 & 0.10 & -0.33 & 0.74 & {$[-0.23,0.16]$} \\
\hline Publication Quality & 1st Tier vs. 2nd Tier & -0.12 & 0.09 & -1.26 & 0.21 & {$[-0.30,0.07]$} \\
\hline \multicolumn{7}{|l|}{ Firm Age \& Innovation } \\
\hline Geography & New vs. Old World & 0.02 & 0.11 & 0.17 & 0.86 & {$[-0.19,0.23]$} \\
\hline Publication Quality & 1st Tier vs. 2nd Tier & 0.11 & 0.12 & 0.95 & 0.34 & {$[-0.12,0.35]$} \\
\hline
\end{tabular}

$* \mathrm{p}<0.05 ; \mathrm{SE}=$ Standard Error; 95\% CI = Confidence Interval for Coefficient

\section{Moderator Analysis}

Table 3 provides a summary of moderator analysis results. We find only two statistically significant moderating effects. First, firm size moderates the relationship between absorptive capacity and innovation $(\bar{r}=0.2022, p<0.0116)$ as expected, indicating a relatively strong interaction. Second, firm size moderates the relationship between export orientation and innovation $(\bar{r}=0.0091, p<0.0392)$; however, the estimated effect size is quite small as compared to the moderating effect of firm size on the relationship between absorptive capacity and innovation. Moderating effects of firm age, geography, and publication quality on all other pairwise relationships are not statistically significant; however, we attribute these results to small sample sizes that constrain the moderator analysis.

\section{DISCUSSION}

\section{Managerial and Policy Implications}

Our meta-analysis has several managerial and policy implications. First, our interpretation of the large positive correlation between innovation and financial performance is twofold. On the one hand, wine firms with higher financial performance may be more likely to allocate their resources to innovation activities than those with lower financial performance. On the other, innovation activities may lead to higher financial performance either directly by granting a competitive advantage to the adopting firm or indirectly via its synergistic spillover and amplification effects. Either way, we believe that this preliminary result looks promising for both wine firms and researchers. Therefore, we encourage wine firms to consider engaging in innovative practices and collaborate with researchers, particularly in quantitative research projects.

Second, we find that wine firms that implement sustainable practices may also be more likely to engage in eco-innovation activities that support these sustainable practices. Eco-innovation, which already constitutes a significant portion of innovation activities in the wine industry, is expected to grow in the near future due to various internal and external factors. Therefore, we suggest that wine firms should invest their resources primarily in eco-innovation activities.

Third, we recommend that wine firms consider adopting emerging industry 4.0 technologies to enhance their existing innovation activities. Besides increasing efficiency of operations, these technologies may accelerate innovations 
by enabling real-time data collection and monitoring (i.e., RFID tags, sensors).

Fourth, our meta-analysis reveals that innovation usually takes place in firms with higher absorptive capacities and successful implementations of innovative practices have the potential to enhance the absorptive capabilities of wine firms. Therefore, we recommend wine firms that would like to compete on innovation invest in their absorptive capacities by training their existing HR, employing highly skilled employees, increasing R\&D activities, establishing links with colleges and research institutions, and patenting innovative ideas.

Fifth, larger firms may be more advantageous in innovation than smaller ones due to their potentially higher absorptive capacities; however, this result should not discourage small firms from engaging in innovative practices. On the contrary, it should encourage them because competing on innovation may be a critical strategy that leverages small firms against large wine firms in the harsh competition, which gets more challenging as new firms join. From this perspective, small wine firms should see innovation as a matter of survival rather than a choice.

Sixth, export-oriented wine firms may be more open to innovation since they typically employ a more diversified and highly skilled workforce with considerable exposure to international standards. External openness may increase their situational awareness, responsiveness to external competitive factors and innovative trends, and willingness to cooperate with research institutions. Therefore, we suggest that wine firms that consider competing on innovation diversify their customer base by entering new markets, employ experts with international experience, and increase their visibility by participating in international competitions and academic conferences.

Finally, our meta-analysis points out a scarcity of quantitative articles focusing on innovations by U.S. wine firms. Most U.S. wine business studies are qualitative papers (i.e., literature review, review, commentary, or descriptive studies). As discussed in the Introduction section, researching innovation in the wine industry is already challenging due to the peculiar characteristics of the wine industry. SMEs dominate the U.S. wine industry with a high concentration of family ownership that prioritizes tradition over innovation. Despite the existing business and knowledge networks, the U.S. wine industry is fragmented, and innovation activities are perceived as business secrets due to high competition. All these factors limit the exchange of information (primarily tacit). In these types of business structures, trust plays a vital role. Quantitative research requires data. Wine firms do have the data. Research collaborations' role in promoting innovation is well established in other sectors (although the link between research institutions and wine firms remains an open question in the wine industry, we believe there is value in research partnerships). Since establishing trust is critical to enable such collaboration, researchers need to convince wine firms that the proposed research will benefit the firm and its outcomes. Some of our findings (i.e., positive association between innovation and financial performance) might be used to justify that. On the other hand, wine firms should accept some risks to realize the potential value of research collaborations. In time, mu- tual understanding and trust would lead to a virtuous cycle in which wine firms and researchers prosper.

\section{Suggestions for Future Research}

Aside from presenting the big picture of academic studies in a particular field, systematic literature reviews contribute to the research efforts by identifying major gaps and strategically directing future research questions. In addition to variants and extensions of already existing studies, we identify eight research gaps. We discuss how future quantitative, qualitative, and interdisciplinary studies may contribute to the innovation-related wine business literature.

\section{Quantitative Studies}

Impact of collaboration between wine firms and research institutions on innovation. Our systematic literature review reveals a shortage of quantitative studies exploring the link between innovation and collaboration with research institutions. We could find only three studies in this area, one of which (Giuliani \& Arza, 2009) provides country-dependent mixed results, as discussed earlier. As the number of studies that report effect sizes from different populations increase, the relationship will be clearer.

Investigation of the link between patent ownership and innovation. We also find a shortage of academic studies that examine the relationship between patent ownership and innovation. The only two studies considering patent ownership in our study pool are Presenza et al. (2017) and Choi \& $\mathrm{Gu}$ (2020). Although wine patents are abundant, the actual impacts of these patents on both wine innovation efforts and financial performance remain unclear. Accessing patent data has never been easier, thanks to the U.S. and EU patent offices. However, researching the impacts of patents on innovation and wine firm performance is challenging for two reasons. First, patents are typically kept as business secrets by wine firms. Second, this type of research requires the identification of specific links between individual patents and their short-, medium-, and long-term impacts on innovation and firm performances, which is somewhat problematic. We recommend future quantitative studies to take on this challenge.

Examination of impacts of other variables on innovation. Finally, we suggest future quantitative studies to focus on the impacts of other potential variables on innovation, such as proximity, corporate social responsibility, national and international regulations, $\mathrm{R} \& \mathrm{D}$ subsidies or tax cuts by governments, competitive pressures from stakeholders, and managers' perceptions regarding innovation. Another research direction is to investigate how climate change stimulates/facilitates innovation efforts with significant implications on financial success. Although there are articles in the literature investigating the impacts of these variables, the number of studies is not sufficient for a meta-analysis.

Using meta-analytic structural equation modeling (MASEM). A possible extension of our meta-analysis is to perform MASEM, to investigate the relationships between different constructs that we use/mention in this study, innovation, and financial performance. MASEM combines the powers of the classical meta-analytic approach and SEM, 
enabling testing hypotheses by fitting structural equation models on a sample of effect sizes. To the best of our knowledge, there is no MASEM study on wine innovation yet.

\section{Qualitative Studies}

Providing a clear definition and classification of innovation in the wine industry. The qualitative research studies reviewed here have provided some unique perspectives of wine innovation from producers worldwide. Still, the research to date has provided little innovation knowledge that may be applied in existing wine businesses, so much more specificity is needed. The studies have highlighted wine producers' key concerns and interests in organic methods (Karagiannis \& Metaxas, 2020; Signori et al., 2017), organic certifications (Ouvrard et al., 2020), and the need for combining traditional methods with new technologies (Vrontis et al., 2016) as ways to innovate in the area of wine production. Going forward, future studies might provide more detail about these innovations that may be useful to winemakers for application. One notable exception is the work of Soceanu et al. (2020), whose experimental study described how wine industry by-products may be sold to various industries to reduce waste and enhance financial performance at the same time.

Organic and sustainability interests were also exhibited in quite a few studies that addressed product innovation, but most likely due to competitive concerns, there was very little specificity about product innovation; topics included new varietals and entry-level wines (Ouvrard et al., 2020), new packaging (Signori et al., 2017), and greater product variety to include organic products (Vrontis et al., 2011). Last, only a few qualitative studies have supplied marketing/communication and organizational innovation findings. (Humphreys \& Carpenter, 2018) suggest a focus on competing by gaining market influence rather than satisfying consumers, while (Vrontis et al., 2016) addressed in a one-firm case study how a family used only family members' promotions rather than traditional mass communication channels. Similarly, little is known about organizational innovations other than potential changes to cultures and structures that may increase competitiveness by allowing for connections with competitors (Signori et al., 2017) and knowledge sharing and integration between family generations (Woodfield \& Husted, 2017).

Comparative investigation of wine innovation before, during, and post-COVID-19. COVID-19 has placed considerable tension on wine supply chains. Many wine firms have faced challenges, such as finding seasonal workers to harvest grapes, decreased cellar-door visits due to restriction on mobility, shifts in consumer behavior (i.e., online shopping), change in sales channels (shift from on-premise to off-premise), and reduction in logistic capacities.Cardebat et al. (2020), for instance, discuss some of these challenges and provide preliminary analysis on the impact of the pandemic on fine wine markets. Similarly, Vergamini et al. (2020) distinguish short- and long-term implications of the pandemic on the wine industry and argue that in the shortterm, wineries that rely on tourism are likely to be negatively affected most. In the long run, large firms will be affected less due to their market power. We suggest that fu- ture qualitative studies conduct similar comparative analyses to identify lessons learned and draw practical insights. As more data becomes available, comparative studies would provide more value to research and practice.

\section{Interdisciplinary Sudies}

Innovation is an interdisciplinary process. One way that wine researchers may contribute to the literature is to collaborate with researchers from other disciplines. Although there are countless interdisciplinary collaboration opportunities, we point out two of them here, operations management (OM) and supply chain management (SCM). We believe that both disciplines may provide significant value to innovation-related wine research.

Application of operations management (OM) methodologies. The pandemic has significantly changed consumer preferences. As online sales and home delivery have gained traction, the need for novel operational solutions (i.e., transportation, inventory management, and home delivery scheduling) have increased. In this regard, we argue that wine business literature should take better advantage of $\mathrm{OM}$ techniques, such as process simulation and online appointment scheduling. Data-driven and prescriptive OM methods may help wine researchers make informed policy recommendations to practitioners. For instance, wine researchers may collaborate with OM researchers to develop process simulation models to test the potential impacts of candidate innovations on firm performance by running various what-if scenarios. Similarly, OM and wine researchers may collaborate to investigate possible benefits of online appointment scheduling methodologies to schedule home deliveries, as well as on-site and online wine tasting sessions, which have become popular during the pandemic. Another interdisciplinary research avenue is to investigate the impact of machine learning-based recommender engines that make real-time customized online wine recommendations to online wine customers. Recommender engines may serve as critical tools for wine firms that seek to increase their online visibility by promoting their wine to targeted wine drinkers based on their preferences. In this regard, we believe that collaboration with OM researchers would accelerate research on wine innovation and provide practical value to the industry.

Exploration of the role that innovation plays in improving supply chain resilience. Supply chain resilience has gained traction during the pandemic, after many tightly optimized beverage chains had failed to respond to shifts in consumer preferences, such as the increase in off-premise (particularly online) and decrease in on-premise sales (Vergamini et al., 2020). One way to improve wine chain resilience is innovation. For instance, blockchain technology can be used to monitor the whole lifecycle of wine from the winery to the table, ensuring real-time traceability and prevent counterfeiting (Danese et al., 2021), and smart vending machines with age verification features may increase wine availability during lockdowns. Automation may decrease reliance on seasonal labor to harvest grapes, and electronic tongues and noses may be used to inspect wine quality (Rodríguez-Méndez et al., 2016). We invite supply chain researchers to collaborate with wine researchers, 
studying what roles innovation may play in improving wine chain resilience.

\section{CONCLUSION}

Measuring innovation in the wine industry is hard not only due to broad, abstract, and ambiguous connotations of the term "innovation" but also owing to peculiar characteristics of the wine industry, which complicate data collection, model building, and analysis. Moreover, innovation activities are often seen as business secrets, which considerably limits the exchange of information among firms and with researchers, slowing down the diffusion of innovation within the wine industry. Despite these challenges, innovation may provide significant value to the industry; however, wine researchers need to convince practitioners that innovation may lead to competitive advantage and bring financial success. We believe that as both the quantity and quality of innovation-related wine research improves, the role that innovation plays in the wine industry would be clearer.

In this study, we provide a systematic review of the relevant wine business literature that consists of 76 studies published since 1991. While providing a narrative review of qualitative studies to identify common wine innovation types and forms, we perform a meta-analysis on the quantitative studies that report usable/convertible effect sizes for pairwise relationships between six commonly used variables (i.e., absorptive capacity, technology adoption, sustainable practices, export orientation, firm size, and firm age) and innovation, as well as the association between innovation and financial performance. Our analysis reveals that absorptive capacity, technology adoption, sustainable practices, export orientation, and firm size are positively correlated with innovation efforts, and innovation is positively associated with financial performance. Furthermore, we find that firm size moderates the relationship between absorptive capacity and innovation. We discuss several managerial and policy implications of our analysis and make a series of recommendations for future research avenues.
Our managerial recommendations include 1) engaging in innovative practices and collaborating with researchers, particularly in quantitative research projects, 2) prioritizing eco-innovation activities, 3) adopting emerging industry 4.0 technologies, 4) investing in absorptive capacity, 5) increasing export-orientation and international visibility.

We suggest future quantitative studies to explore the impacts of 1) links to research institutions, 2) patent ownership, 3) and other variables, such as proximity, corporate social responsibility, national and international regulations, R\&D subsidies by governments, competitive pressures from stakeholders, and the managerial perceptions regarding innovation and financial performance. We also recommend researchers consider conducting MASEM, which currently does not exist in the literature. We recommend future qualitative research efforts to focus on clearly defining and classifying innovation in the wine sector and comparing the performances of wine supply chains before, during, and after the pandemic to exemplify how innovation has helped wine firms recover from disruptions caused by the pandemic. Finally, to mitigate the negative impacts of the recent pandemic on wine supply chains, we suggest that wine business research should benefit from interdisciplinary studies more, particularly with operations management and supply chain management fields.

This study has two main limitations. First, our metaanalysis relies on a relatively small number of effect sizes. As the number of studies in wine innovation increases, we expect a meta-analytic approach to provide a better picture of investigated relationships. Second, we convert certain effect sizes into Pearson correlation coefficients using some approximations, which increase prediction error. We suggest future quantitative studies to report correlation matrices. This would eliminate the need for effect size conversions and reduce errors in meta-analysis.

Submitted: June 29, 2021 PDT, Accepted: December 10, 2021 PDT 


\section{References}

Ahn, J. M., Mortara, L., \& Minshall, T. (2013). The effects of open innovation on firm performance: a capacity approach. STI Policy Review, 4, 79-93.

Alant, K., \& Bruwer, J. (2004). Wine tourism behaviour in the context of a motivational framework for wine regions and cellar doors. Journal of Wine Research, 15(1), 27-37. https://doi.org/10.1080/0957126042000 $\underline{300308}$

Annunziata, E., Pucci, T., Frey, M., \& Zanni, L. (2018). The role of organizational capabilities in attaining corporate sustainability practices and economic performance: Evidence from Italian wine industry. Journal of Cleaner Production, 171, 1300-1311.

Atkin, T., Gilinsky, A. J., \& Newton, S. K. (2012). Environmental strategy: Does it lead to competitive advantage in the US wine industry? International Journal of Wine Business Research, 24(2), 115-133. htt ps://doi.org/10.1108/17511061211238911

Atkin, T., \& Johnson, R. (2010). Appellation as an indicator of quality. International Journal of Wine Business Research, 22(1), 42-61. https://doi.org/10.11 $\underline{08 / 17511061011035198}$

Barney, J. (1991). Firm resources and sustained competitive advantage. Journal of Management, 17, 99-120.

Barney, J. (1999). Gaining and Sustaining Competitive Advantage. Addison-Wesley.

Baumeister, R. F., \& Leary, M. R. (1997). Writing Narrative Literature Reviews. Review of General Psychology, 1(3), 311-320. https://doi.org/10.1037/10 89-2680.1.3.311

Bruwer, J., \& Li, E. (2007). Wine-related lifestyle (WRL) market segmentation: Demographic and behavioural factors. Journal of Wine Research, 18(1), 19-34. http s://doi.org/10.1080/09571260701526865

Calle, F., González-Moreno, Á., Carrasco, I., \& VargasVargas, M. (2020). Social Economy, Environmental Proactivity, Eco-Innovation and Performance in the Spanish Wine Sector. Sustainability, 12(15), 5908. http s://doi.org/10.3390/su12155908

Cardebat, J.-M., Masset, P., \& Weisskopf, J.-P. (2020). COVID-19: What is Next for the Market for Fine Wines? SSRN Electronic Journal. https://doi.org/10.21 39/ssrn.3636317

Carlsen, J. (2004). A review of global wine tourism research. Journal of Wine Research, 15(1), 5-13. http s://doi.org/10.1080/0957126042000300281

Choi, H., \& Gu, C. (2020). Geospatial Response for Innovation in the Wine Industry: Knowledge Creation through Institutional Mobility in China. Agronomy, 10(4), 495. https://doi.org/10.3390/agronomy1004049 $\underline{5}$

Chrisman, J. J., \& Patel, P. C. (2012). Variations in R\&D investments of family and nonfamily firms: Behavioral agency and myopic loss aversion perspectives. Academy of Management Journal, 55(4), 976-997. https://doi.org/10.5465/amj.2011.0211
Cohen, W. M., \& Levinthal, D. A. (1990). Absorptive capacity: A new perspective on learning and innovation. Administrative Science Quarterly, 128-152.

Colbert, S., Wilkinson, C., Thornton, L., \& Richmond, R. (2020). COVID-19 and alcohol in Australia: Industry changes and public health impacts. Drug and Alcohol Review, 39(5), 435-440. https://doi.org/10.1111/dar.1 $\underline{3092}$

Cradock-Henry, N. A., \& Fountain, J. (2019). Characterising resilience in the wine industry: Insights and evidence from Marlborough, New Zealand. Environmental Science \& Policy, 94, 182-190. https://doi.org/10.1016/j.envsci.2019.01.015

Damanpour, F. (1991). Organizational innovation: A meta-analysis of effects of determinants and moderators. Academy of Management Journal, 34(3), 555-590.

Danese, P., Mocellin, R., \& Romano, P. (2021). Designing blockchain systems to prevent counterfeiting in wine supply chains: a multiple-case study. International Journal of Operations \& Production Management.

Delacroix, J., \& Swaminathan, A. (1991). Cosmetic, speculative, and adaptive organizational change in the wine industry: A longitudinal study. Administrative Science Quarterly, 36(4), 631. https://do i.org $/ 10.2307 / 2393277$

Doloreux, D., Chamberlin, T., \& Ben-Amor, S. (2013). Modes of innovation in the Canadian wine industry. International Journal of Wine Business Research, 25(1), 6-26. https://doi.org/10.1108/17511061311317282

Doloreux, D., \& Frigon, A. (2019). Understanding innovation in Canadian wine regions: An exploratory study. British Food Journal, 121(4), 882-896. https://d oi.org/10.1108/bfj-10-2018-0691

Doloreux, D., \& Lord-Tarte, E. (2013). The organisation of innovation in the wine industry. European Journal of Innovation Management, 16(2), 171-189. https://do i.org/10.1108/14601061311324520

Doloreux, D., Shearmur, R., Porto-Gomez, I., \& Zabala-Iturriagagoitia, J. M. (2020). DUI and STI innovation modes in the Canadian wine industry: The geography of interaction modes. Growth and Change, 51(3), 890-909. https://doi.org/10.1111/grow.12385

Dressler, M. (2013). Innovation management of German wineries: From activity to capacity-an explorative multi-case survey. Wine Economics and Policy, 2(1), 19-26. https://doi.org/10.1016/j.wep.2013.05.002

Dries, L., Pascucci, S., Török, Á., \& Tóth, J. (2014). Keeping your secrets public? Open versus closed innovation processes in the Hungarian wine sector. International Food and Agribusiness Management Review, 17(1030-2016-82970), 147-162.

Ettlie, J. E., Bridges, W. P., \& O’keefe, R. (1984). Organization strategy and structural differences for radical versus incremental innovation. Management Science, 30, 682-695. 
Faccin, K., Genari, D., \& Macke, J. (2017). Interorganisational social capital and innovation: a multiple case study in wine producers networks in Serra Gaúcha. RAI Revista de Administração e Inovação, 14, 52-66.

Fiore, M., Silvestri, R., Contò, F., \& Pellegrini, G. (2017). Understanding the relationship between green approach and marketing innovations tools in the wine sector. Journal of Cleaner Production, 142, 4085-4091.

Frigon, A., Doloreux, D., \& Shearmur, R. (2020). Drivers of eco-innovation and conventional innovation in the Canadian wine industry. Journal of Cleaner Production, 275, 124115.

Galati, A., Crescimanno, M., Tinervia, S., \& Fagnani, F. (2017). Social media as a strategic marketing tool in the Sicilian wine industry: Evidence from Facebook. Wine Economics and Policy, 6(1), 40-47. https://doi.or $\mathrm{g} / 10.1016 /$ i.wep.2017.03.003

Galbreath, J. (2005). Which resources matter the most to firm success? An exploratory study of resource-based theory. Technovation, 25, 979-987.

Galbreath, J., Charles, D., \& Oczkowski, E. (2016). The drivers of climate change innovations: evidence from the Australian wine industry. Journal of Business Ethics, 135, 217-231.

Garcia, R., \& Atkin, T. (2007). Co-opetition for the diffusion of resistant innovations: A case study in the global wine industry using an agent-based model. 25th International Conference of the System Dynamics Society, 3.

Gault, F. (2018). Defining and measuring innovation in all sectors of the economy. Research Policy, 47, 617-622.

Giacomarra, M., Galati, A., Crescimanno, M., \& Tinervia, S. (2016). The integration of quality and safety concerns in the wine industry: The role of third-party voluntary certifications. Journal of Cleaner Production, 112, 267-274. https://doi.org/10.1016/i.jcl epro.2015.09.026

Gilinsky, A., Newton, S. K., \& Vega, R. F. (2016). Sustainability in the global wine industry: Concepts and cases. Agriculture and Agricultural Science Procedia, 8, 37-49.

Gilinsky, A., Santini, C., Lazzeretti, L., \& Eyler, R. (2008). Desperately seeking serendipity: Exploring the impact of country location on innovation in the wine industry. International Journal of Wine Business Research, 20(4), 302-320. https://doi.org/10.1108/175 11060810919425

Giuliani, E. (2007). The selective nature of knowledge networks in clusters: Evidence from the wine industry. Journal of Economic Geography, 7(2), 139-168. https://doi.org/10.1093/jeg/lbl014

Giuliani, E., \& Arza, V. (2009). What drives the formation of 'valuable'university-industry linkages?: Insights from the wine industry. Research Policy, 38, 906-921.

Giuliani, E., \& Bell, M. (2005). The micro-determinants of meso-level learning and innovation: evidence from a Chilean wine cluster. Research Policy, 34, 47-68.
Grant, R. M. (2015). Knowledge-Based View. In Wiley Encyclopedia of Management (Vols. 1-2).

Guerrero-Villegas, J., Sierra-García, L., \& PalaciosFlorencio, B. (2018). The role of sustainable development and innovation on firm performance. Corporate Social Responsibility and Environmental Management, 25, 1350-1362.

Hojman, D. E. (2015). Radical innovation in luxury carmenere wine from Chile. Journal of Wine Research, 26(1), 40-63. https://doi.org/10.1080/09571264.201 4.992398

Hu, X., \& Yang, Y. (2021). What makes online reviews helpful in tourism and hospitality? a bare-bones meta-analysis. Journal of Hospitality Marketing \& Management, 30, 139-158.

Humphreys, A., \& Carpenter, G. S. (2018). Status games: Market driving through social influence in the US wine industry. Journal of Marketing, 82, 141-159.

Hunter, J. E., \& Schmidt, F. L. (1990). Dichotomization of continuous variables: The implications for metaanalysis. Journal of Applied Psychology, 75, 334.

Hunter, J. E., \& Schmidt, F. L. (2000). Fixed effects vs. random effects meta-analysis models: Implications for cumulative research knowledge. International Journal of Selection and Assessment, 8, 275-292.

Hunter, J. E., \& Schmidt, F. L. (2004). Methods of metaanalysis: Correcting error and bias in research findings. Sage.

Hunter, J. E., Schmidt, F. L., \& Jackson, G. B. (1981). Integrating research findings across studies. American Psychological Association Division 14 Conference, Methodological Innovations in Studying Organization.

Johnson, R., \& Bruwer, J. (2007). Regional brand image and perceived wine quality: The consumer perspective. International Journal of Wine Business Research, 19(4), 276-297. https://doi.org/10.1108/175 11060710837427

Karagiannis, D., \& Metaxas, T. (2020). Sustainable Wine Tourism Development: Case Studies from the Greek Region of Peloponnese. Sustainability, 12, 5223.

Kavadias, S., \& Ulrich, K. T. (2020). Innovation and new product development: Reflections and insights from the research published in the first 20 years of manufacturing \& service operations management. Manufacturing \& Service Operations Management, 22, 84-92.

Kemp, R., \& Pearson, P. (2007). Final report MEI project about measuring eco-innovation. UM Merit, Maastricht, 10.

Knight, H., Megicks, P., Agarwal, S., \& Leenders, M. A. (2019). Firm resources and the development of environmental sustainability among small and medium-sized enterprises: Evidence from the Australian wine industry. Business Strategy and the Environment, 28, 25-39.

Laguna, L., Fiszman, S., Puerta, P., Chaya, C., \& Tárrega, A. (2020). The impact of COVID-19 lockdown on food priorities. Results from a preliminary study using social media and an online survey with Spanish consumers. Food Quality and Preference, 86, 104028. 
Leenders, M. A., \& Chandra, Y. (2013). Antecedents and consequences of green innovation in the wine industry: The role of channel structure. Technology Analysis \& Strategic Management, 25(2), 203-218. htt ps://doi.org/10.1080/09537325.2012.759203

Li, H., Wang, H., Li, H., Goodman, S., van der Lee, P., $\mathrm{Xu}, \mathrm{Z}$., Fortunato, A., \& Yang, P. (2018). The worlds of wine: Old, new and ancient. Wine Economics and Policy, 7(2), 178-182. https://doi.org/10.1016/j.wep.20 18.10.002

Li, Y., \& Bardají, I. (2017). A new wine superpower? An analysis of the Chinese wine industry. Cahiers Agricultures, 26(6), 65002. https://doi.org/10.1051/cag $\underline{\mathrm{ri} / 2017051}$

Li, Z., Zhang, S., Liu, X., Kozak, M., \& Wen, J. (2020). Seeing the invisible hand: Underlying effects of COVID-19 on tourists' behavioral patterns. Journal of Destination Marketing \& Management, 18, 100502. htt ps://doi.org/10.1016/i.jdmm.2020.100502

Lipsey, M. W., \& Wilson, D. B. (2001). Practical metaanalysis. SAGE publications, Inc.

Lorenzo, J. R., Rubio, M. T., \& Garcés, S. A. (2018). The competitive advantage in business, capabilities and strategy. What general performance factors are found in the Spanish wine industry? Wine Economics and Policy, 7, 94-108.

Maurel, C. (2009). Determinants of export performance in French wine SMEs. International Journal of Wine Business Research.

Melnyk, S. A., Sroufe, R. P., \& Calantone, R. (2003). Assessing the impact of environmental management systems on corporate and environmental performance. Journal of Operations Management, 1(21), 329-351. https://doi.org/10.1016/s0272-6963(0 2)00109-2

Menna, A., \& Walsh, P. R. (2019). Assessing environments of commercialization of innovation for SMEs in the global wine industry: A market dynamics approach. Wine Economics and Policy, 8(2), 191-202. $\underline{\mathrm{h}}$ ttps://doi.org/10.1016/j.wep.2019.10.001

Moreno, M. d., García-Pardo, I. P., \& de Pablo González, J. D. (2011). Factors of competitiveness in the wine industry: An analysis of innovation strategy. International Journal of Economics and Management Engineering, 5(6), 847-857.

Morrison, A., \& Rabellotti, R. (2017). Gradual catch up and enduring leadership in the global wine industry. Research Policy, 46(2), 417-430. https://doi.org/10.101 6/j.respol.2016.09.007

Murovec, N., \& Prodan, I. (2008). The influence of organizational absorptive capacity on product and process innovation. Organizacija, 41.

Muscio, A., Nardone, G., \& Stasi, A. (2013). Drivers of eco-innovation in the Italian wine industry. Proceedings of the 6th International European Forum on System Dynamics and Innovation in Food Networks.

Muscio, A., Nardone, G., \& Stasi, A. (2015). Drivers of eco-innovation in the wine industry. DRUID15, 15-17.
Neufeld, M., Lachenmeier, D. W., Ferreira-Borges, C., \& Rehm, J. (2020). Is Alcohol an "Essential Good" During COVID-19? Yes, but Only as a Disinfectant! Alcoholism: Clinical and Experimental Research, 44(9), 1906-1909. https://doi.org/10.1111/acer.14417

Ouvrard, S., Jasimuddin, S. M., \& Spiga, A. (2020). Does Sustainability Push to Reshape Business Models? Evidence from the European Wine Industry. Sustainability, 12, 2561.

Pabst, E., Szolnoki, G., \& Loose, S. M. (2019). How will mandatory nutrition and ingredient labelling affect the wine industry? A quantitative study of producers' perspectives. Wine Economics and Policy, 8(2), 103-113. https://doi.org/10.1016/j.wep.2019.05.002

Penn, C. (2021). Just in Time Just Isn't Enough: COVID-19 Crisis Strains Supply Chain. Wine Business Monthly, 140-148.

Peterson, R. A., \& Brown, S. P. (2005). On the use of beta coefficients in meta-analysis. Journal of Applied Psychology, 90, 175.

Porto-Gómez, I., Larreina, M., \& Gaviria-de-la-Puerta, J. (2020). Does wine innovation research require ageing? A bibliometric review. El Profesional de La Información, 29(6). https://doi.org/10.3145/epi.2020.n ov. 15

Pradana, M., Pérez-Luño, A., \& Fuentes-Blasco, M. (2020). Innovation as the key to gain performance from absorptive capacity and human capital. Technology Analysis \& Strategic Management, 32, 822-834.

Presenza, A., Abbate, T., Meleddu, M., \& Cesaroni, F. (2017). Small-and medium-scale Italian winemaking companies facing the open innovation challenge. International Small Business Journal, 35, 327-348.

Quintana, D. S. (2015). From pre-registration to publication: a non-technical primer for conducting a meta-analysis to synthesize correlational data. Frontiers in Psychology, 6, 1549.

Rodríguez-Méndez, M. L., De Saja, J. A., GonzálezAntón, R., García-Hernández, C., Medina-Plaza, C., García-Cabezón, C., \& Martín-Pedrosa, F. (2016). Electronic noses and tongues in wine industry. Frontiers in Bioengineering and Biotechnology, 4, 81.

Sacchelli, S., Fabbrizzi, S., \& Menghini, S. (2016). Climate change effects and adaptation strategies in the wine sector: A quantitative literature review. Wine Economics and Policy, 5(2), 114-126. https://doi.org/1 0.1016/j.wep.2016.08.001

Scaringella, L., \& Radziwon, A. (2018). Innovation, entrepreneurial, knowledge, and business ecosystems: Old wine in new bottles? Technological Forecasting and Social Change, 136, 59-87. https://do i.org/10.1016/j.techfore.2017.09.023

Schimmenti, E., Migliore, G., Di Franco, C. P., \& Borsellino, V. (2016). Is there sustainable entrepreneurship in the wine industry? Exploring Sicilian wineries participating in the SOStain program. Wine Economics and Policy, 5(1), 14-23. http s://doi.org/10.1016/i.wep.2016.05.001 
Schultz, H. R., \& Jones, G. V. (2010). Climate induced historic and future changes in viticulture. Journal of Wine Research, 21(2-3), 137-145. https://doi.org/10.1 $\underline{080 / 09571264.2010 .530098}$

Signori, P., Flint, D. J., \& Golicic, S. L. (2017). Constrained innovation on sustainability in the global wine industry. Journal of Wine Research, 28, 71-90.

Snyder, H. (2019). Literature review as a research methodology: An overview and guidelines. Journal of Business Research, 104, 333-339. https://doi.org/10.10 16/j.jbusres.2019.07.039

Soceanu, A., Dobrinas, S., Sirbu, A., Manea, N., \& Popescu, V. (2020). Economic aspects of waste recovery in the wine industry. A multidisciplinary approach. Science of The Total Environment, 143543.

Sroufe, R. (2009). Effects of environmental management systems on environmental management practices and operations. Production and Operations Management, 12(3), 416-431. https://doi.org/10.1111/j.1937-5956.2 003.tb00212.x

Stasi, A., Muscio, A., Nardone, G., \& Seccia, A. (2016). New technologies and sustainability in the Italian wine industry. Agriculture and Agricultural Science Procedia, 8, 290-297.

Štastná, M., Vaishar, A., Ryglová, K., Rašovská, I., \& Zámečník, S. (2020). Cultural Tourism as a Possible Driver of Rural Development in Czechia. Wine Tourism in Moravia as a Case Study. European Countryside, 12(3), 292-311. https://doi.org/10.2478/e uco-2020-0017

Tyler, B., Lahneman, B., Beukel, K., Cerrato, D., Minciullo, M., Spielmann, N., \& Discua Cruz, A. (2020). SME managers' perceptions of competitive pressure and the adoption of environmental practices in fragmented industries: A multi-country study in the wine industry. Organization \& Environment, 33(3), 437-463. https://doi.org/10.1177/1086026618803720

Ugaglia, A. A., \& Ouvrard, S. (2020). Blending Tradition and Innovation in Bordeaux: A Differentiation Strategy for Château Luchey-Halde. Wine Business Case Research Journal, 1-20.
Utterback, J. M., \& Abernathy, W. J. (1975). A dynamic model of process and product innovation. Omega, 3 , 639-656.

Van Leeuwen, C., \& Seguin, G. (2006). The concept of terroir in viticulture. Journal of Wine Research, 17, $1-10$.

Vaudour, E. (2002). The quality of grapes and wine in relation to geography: Notions of terroir at various scales. Journal of Wine Research, 13, 117-141.

Vergamini, D., Bartolini, F., \& Brunori, G. (2020). Wine after the pandemic? All the doubts in a glass. $A B C$.

Vidoli, F., Cardillo, C., Fusco, E., \& Canello, J. (2016). Spatial nonstationarity in the stochastic frontier model: An application to the Italian wine industry. Regional Science and Urban Economics, 61, 153-164. ht tps://doi.org/10.1016/j.regsciurbeco.2016.10.003

Vrontis, D., Bresciani, S., \& Giacosa, E. (2016). Tradition and innovation in Italian wine family businesses. British Food Journal.

Vrontis, D., Thrassou, A., \& Rossi, M. (2011). Italian wine firms: strategic branding and financial performance. International Journal of Organizational Analysis.

Walker, D. A. (2003). Converting Kendall's tau for correlational or meta-analytic analyses. Journal of Modern Applied Statistical Methods, 2(3), 525-530.

Williams, C., \& Spielmann, N. (2019). Institutional pressures and international market orientation in SMEs: Insights from the French wine industry. International Business Review, 28(5), 101582. https://d oi.org/10.1016/j.ibusrev.2019.05.002

Woodfield, P., \& Husted, K. (2017). Intergenerational knowledge sharing in family firms: Case-based evidence from the New Zealand wine industry. Journal of Family Business Strategy, 8, 57-69.

Zheng, Q., \& Wang, H. H. (2017). Market power in the Chinese wine industry. Agribusiness, 33(1), 30-42. htt ps://doi.org/10.1002/agr.21479 
Table A1. List of Abbreviations

\begin{tabular}{|c|c|c|c|}
\hline \multicolumn{4}{|c|}{ Theories } \\
\hline BAM & Behavioral Agency Model (Theory) & PDT & Psychological Distance Theory \\
\hline CBT & Consumer Behavior Theory & QT & Quality Theory \\
\hline CLT & Construal Level Theory & RBV & Resource Based View \\
\hline CSRT & Corporate Social Responsibility Theory & RIT & Resistant Innovation Theory \\
\hline CT & Competitive Theory & RT & Resilience Theory \\
\hline CU & Catch-up Theory & SP & Systems Perspective \\
\hline EIT & Eco-Innovation Theory & SEPR & Socio Economic Perspective on Resilience \\
\hline GPT & Geographical Proximity Theory & SIT & Social Influence Theory \\
\hline GT & Grounded Theory & SMT & Social Media Theory \\
\hline IT & Institutional Theory & SNT & Social Network Theory \\
\hline KBV & Knowledge Based View & ST & Sustainability Theory \\
\hline OBT & Organizational Behavior Theory & UET & Upper Echelons Theory \\
\hline OIT & Open Innovation Theory & WCF & Walsh's Conceptual Framework \\
\hline OLT & Organizational Learning Theory & wo & Windows of Opportunity Theory \\
\hline \multicolumn{4}{|c|}{ Methodologies } \\
\hline ABM & Agent-Based Modeling & OLS & Ordinary Least Squares \\
\hline CATI & Computer Assisted Telephone Interview & PCA & Principal Component Analysis \\
\hline EDA & Exploratory Data Analysis & PLS & Partial Least Squares \\
\hline EHA & Event History Analysis & QA & Qualitative Analysis \\
\hline FAM & Factor Analytic Method & Reg. & Regression \\
\hline GNA & Geospatial Network Analysis & SEM & Structural Equation Modeling \\
\hline Hier. & Hierarchical & SMA & Social Media Analysis \\
\hline IPA & Importance Performance Analysis & SNA & Social Network Analysis \\
\hline MMPR & Mixed-Method Participatory Research & SSFA & Spatial Stochastic Frontier Analysis \\
\hline NPT & Non-parametric Test & Log. & Logistic \\
\hline \multicolumn{4}{|l|}{ Other } \\
\hline $\mathrm{BN}$ & Business Network & KB & Knowledge Base \\
\hline DTC & Direct to Customer & PEP & Proactive environmental practices \\
\hline IMO & International market orientation & $R \& D$ & Research and Development \\
\hline $\mathrm{KN}$ & Knowledge Network & & \\
\hline
\end{tabular}

Table A5. Tests of Publication Bias

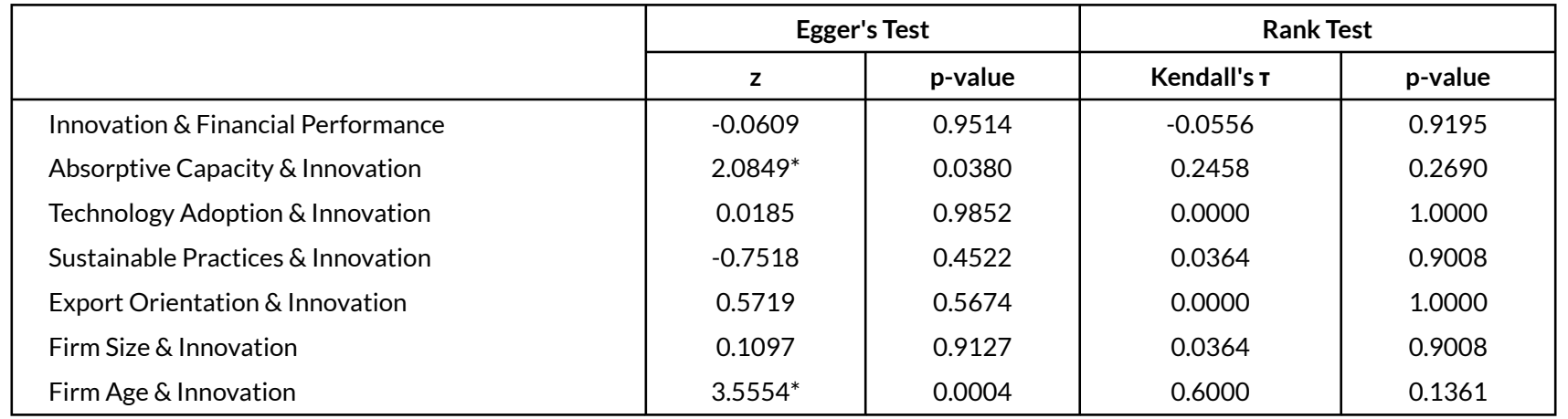

\section{APPENDIX}


Table A2. List of Quantitative Studies Used in the Meta-Analysis

\begin{tabular}{|c|c|c|c|c|}
\hline Paper & Theory & Methodology & $\begin{array}{l}\text { Independent } \\
\text { Variable(s) }\end{array}$ & $\begin{array}{l}\text { Dependent } \\
\text { Variable(s) }\end{array}$ \\
\hline $\begin{array}{l}\text { Calle et al. } \\
(2020)\end{array}$ & EIT, ST & $\begin{array}{l}\text { T-test, PCA, } \\
\text { ANOVA, } \\
\text { Clustering }\end{array}$ & $\begin{array}{l}\text { Legal form } \\
\text { (cooperatives } \\
\text { vs. non- } \\
\text { cooperatives) }\end{array}$ & $\begin{array}{l}\text { Environmental } \\
\text { behavior }\end{array}$ \\
\hline
\end{tabular}

Contribution

No significant difference between cooperative and non-cooperative wine firms regarding their environmental behavior (i.e., proactive, preventive, and activist behavior).

\begin{tabular}{lllll}
$\begin{array}{l}\text { Doloreux et } \\
\text { al. (2020) }\end{array}$ & RBV & Log.-Reg. & $\begin{array}{l}\text { DUI, STI, R\&D, } \\
\text { Firm Size }\end{array}$ & $\begin{array}{l}\text { Types of } \\
\text { Innovation }\end{array}$ \\
& & & \\
& & & \\
\hline $\begin{array}{l}\text { Frigon et al. } \\
(2020)\end{array}$ & EIT, & Log.-Reg. & $\begin{array}{l}\text { Internal and } \\
\text { external } \\
\text { innovation } \\
\text { activities }\end{array}$ & $\begin{array}{l}\text { Conventional } \\
\text { and eco- } \\
\text { innovations }\end{array}$ \\
& RBV & & &
\end{tabular}

Wine firms may enhance innovation via Scientific and Technologically based Innovation (STI) and Doing, Using, and Interacting (DUI) activities.

\begin{tabular}{|c|c|c|c|c|c|}
\hline $\begin{array}{l}\text { Frigon et al. } \\
(2020)\end{array}$ & $\begin{array}{l}\text { EIT, } \\
\text { RBV }\end{array}$ & Log.-Reg. & $\begin{array}{l}\text { Internal and } \\
\text { external } \\
\text { innovation } \\
\text { activities }\end{array}$ & $\begin{array}{l}\text { Conventional } \\
\text { and eco- } \\
\text { innovations }\end{array}$ & $\begin{array}{l}\text { Both conventional and eco- } \\
\text { innovation are associated } \\
\text { with internal factors, but } \\
\text { eco-innovation is more } \\
\text { closely related to external } \\
\text { factors. }\end{array}$ \\
\hline $\begin{array}{l}\text { Pradana et al. } \\
\text { (2020) }\end{array}$ & RBV & PLS-Reg. & $\begin{array}{l}\text { Absorptive } \\
\text { capacity, human } \\
\text { capital }\end{array}$ & $\begin{array}{l}\text { Innovation, } \\
\text { financial } \\
\text { performance }\end{array}$ & $\begin{array}{l}\text { Absorptive capacity and } \\
\text { human capital are positively } \\
\text { associated with innovation } \\
\text { and financial performance. }\end{array}$ \\
\hline $\begin{array}{l}\text { Tyler et al. } \\
(2020)\end{array}$ & $\begin{array}{l}\text { UET, } \\
\text { CT }\end{array}$ & OLS-Reg. & $\begin{array}{l}\text { Environmental } \\
\text { practices, } \\
\text { perception of } \\
\text { competitive } \\
\text { pressure }\end{array}$ & $\begin{array}{l}\text { Environmental } \\
\text { practices, } \\
\text { financial } \\
\text { performance }\end{array}$ & $\begin{array}{l}\text { Weaker competitive } \\
\text { pressure is positively } \\
\text { associated with the } \\
\text { adoption of eco-practices. } \\
\text { Stronger competitive } \\
\text { pressure positively } \\
\text { moderates the relationship } \\
\text { between the adoption of } \\
\text { eco-practices and financial } \\
\text { performance. }\end{array}$ \\
\hline $\begin{array}{l}\text { Doloreux \& } \\
\text { Frigon (2019) }\end{array}$ & $\begin{array}{l}\text { OIT, } \\
\text { GPT, } \\
\text { RBV }\end{array}$ & $\begin{array}{l}\text { PCA } \\
\text { Clustering }\end{array}$ & $\begin{array}{l}\text { Innovation } \\
\text { strategy, } \\
\text { expenditure, } \\
\text { knowledge } \\
\text { sourcing }\end{array}$ & $\begin{array}{l}\text { Clustering } \\
\text { based on the } 4 \\
\text { innovation } \\
\text { modes }\end{array}$ & $\begin{array}{l}\text { Innovation modes are } \\
\text { associated with different } \\
\text { innovation outputs, some } \\
\text { innovation modes better } \\
\text { reflect certain firms in three } \\
\text { wine regions in Canada. }\end{array}$ \\
\hline $\begin{array}{l}\text { Knight et al. } \\
\text { (2019) }\end{array}$ & RBV & PLS SEM & $\begin{array}{l}\text { Brand, service, } \\
\text { financial, and } \\
\text { innovation } \\
\text { performances }\end{array}$ & $\begin{array}{l}\text { Environmental } \\
\text { behavior, } \\
\text { environmental } \\
\text { disclosure }\end{array}$ & $\begin{array}{l}\text { Brand, service, and } \\
\text { innovation performances } \\
\text { are positively associated } \\
\text { with environmental } \\
\text { behavior, innovation } \\
\text { performance is positively } \\
\text { associated with } \\
\text { environmental disclosure. }\end{array}$ \\
\hline $\begin{array}{l}\text { Menna \& } \\
\text { Walsh (2019) }\end{array}$ & WCF & $\begin{array}{l}\text { K-means } \\
\text { Clustering }\end{array}$ & $\begin{array}{l}\text { Wine prod. (\% } \\
\text { of GDP), \% } \\
\text { growth in } \\
\text { prod./acre, \# of } \\
\text { programs in } \\
\text { vineology }\end{array}$ & $\begin{array}{l}\text { Number of } \\
\text { clusters }\end{array}$ & $\begin{array}{l}\text { Using data from 2011-2014 } \\
\text { classifies } 22 \text { OECD } \\
\text { countries into one of four } \\
\text { clusters (i.e., Innovation } \\
\text { Wasteland, Innovation } \\
\text { Nirvana, Innovation Push, } \\
\text { Innovation Pull). }\end{array}$ \\
\hline $\begin{array}{l}\text { Williams \& } \\
\text { Spielmann } \\
(2019)\end{array}$ & IT & OLS.-Reg. & $\begin{array}{l}\text { National laws, } \\
\text { international } \\
\text { laws, } \\
\text { distributors, } \\
\text { end consumers }\end{array}$ & $\begin{array}{l}\text { International } \\
\text { market } \\
\text { orientation } \\
\text { (IMO) }\end{array}$ & $\begin{array}{l}\text { The greater the pressure } \\
\text { from national laws, the } \\
\text { lower the IMO. The greater } \\
\text { the pressure from } \\
\text { international laws, the } \\
\text { greater the IMO. The } \\
\text { pressures from distributors } \\
\text { and consumers positively } \\
\text { and negatively affect the } \\
\text { IMO. }\end{array}$ \\
\hline
\end{tabular}




\begin{tabular}{|c|c|c|c|c|c|}
\hline Paper & Theory & Methodology & $\begin{array}{l}\text { Independent } \\
\text { Variable(s) }\end{array}$ & $\begin{array}{l}\text { Dependent } \\
\text { Variable(s) }\end{array}$ & Contribution \\
\hline $\begin{array}{l}\text { Lorenzo et al. } \\
\text { (2018) }\end{array}$ & RBV & $\begin{array}{l}\text { PCA, Hier.- } \\
\text { Reg. }\end{array}$ & $\begin{array}{l}\text { Technological } \\
\text { capability, } \\
\text { management, } \\
\text { business } \\
\text { strategy }\end{array}$ & $\begin{array}{l}\text { Financial } \\
\text { performance }\end{array}$ & $\begin{array}{l}\text { Individual firms achieve } \\
\text { superior financial } \\
\text { performance via a cost } \\
\text { leadership strategy. The } \\
\text { technological capabilities of } \\
\text { mercantile firms and } \\
\text { cooperatives are positively } \\
\text { associated with their } \\
\text { financial performance. }\end{array}$ \\
\hline $\begin{array}{l}\text { Faccin et al. } \\
(2017)\end{array}$ & SNT & OLS-Reg. & $\begin{array}{l}\text { Social capital, } \\
\text { competitiveness }\end{array}$ & Innovation & $\begin{array}{l}\text { Competitiveness and } \\
\text { innovation are positively } \\
\text { correlated. There are also } \\
\text { positive relationships } \\
\text { between social capital and } \\
\text { competitiveness, and social } \\
\text { capital and innovation. }\end{array}$ \\
\hline $\begin{array}{l}\text { Fiore et al. } \\
(2017)\end{array}$ & EIT & $\begin{array}{l}\text { Correlation } \\
\text { Analysis }\end{array}$ & $\begin{array}{l}\text { Orientation to } \\
\text { sustainability }\end{array}$ & $\begin{array}{l}\text { Marketing } \\
\text { innovation } \\
\text { choices }\end{array}$ & $\begin{array}{l}\text { Wineries with marketing } \\
\text { innovation tools are more } \\
\text { oriented towards } \\
\text { sustainable practices. }\end{array}$ \\
\hline $\begin{array}{l}\text { Galati et al. } \\
(2017)\end{array}$ & $\begin{array}{l}\text { RBV, } \\
\text { SMT }\end{array}$ & $\begin{array}{l}\text { Two-stage } \\
\text { Cluster } \\
\text { Analysis }\end{array}$ & $\begin{array}{l}\text { Intensity, } \\
\text { richness, and } \\
\text { responsiveness }\end{array}$ & $\begin{array}{l}\text { Number of } \\
\text { clusters }\end{array}$ & $\begin{array}{l}\text { Small firms are more } \\
\text { engaged in social media } \\
\text { activity than large firms. } \\
\text { Firms managed by CEOs } \\
\text { with high education levels } \\
\text { are more engaged in social } \\
\text { media activity. }\end{array}$ \\
\hline $\begin{array}{l}\text { Presenza et } \\
\text { al. (2017) }\end{array}$ & $\begin{array}{l}\text { RBV, } \\
\text { OIT }\end{array}$ & $\begin{array}{l}\text { PCA Log.- } \\
\text { Reg. }\end{array}$ & $\begin{array}{l}\text { External } \\
\text { knowledge } \\
\text { sources, } \\
\text { technological } \\
\text { capabilities, } \\
\text { competitive } \\
\text { pressures }\end{array}$ & $\begin{array}{l}\text { Process or } \\
\text { product } \\
\text { innovation }\end{array}$ & $\begin{array}{l}\text { Firms that use external } \\
\text { knowledge sources are } \\
\text { more innovative and their } \\
\text { absorptive capacity impacts } \\
\text { the use of external sources. }\end{array}$ \\
\hline $\begin{array}{l}\text { Guerrero- } \\
\text { Villegas et al. } \\
\text { (2018) }\end{array}$ & CSRT & PLS & $\begin{array}{l}\text { Corporate } \\
\text { social } \\
\text { responsibility } \\
\text { (CSR), } \\
\text { Innovation }\end{array}$ & $\begin{array}{l}\text { Objective and } \\
\text { subjective } \\
\text { Performance }\end{array}$ & $\begin{array}{l}\text { CSR positively affects } \\
\text { performance via mediating } \\
\text { effect of innovation. }\end{array}$ \\
\hline $\begin{array}{l}\text { Zheng \& } \\
\text { Wang (2017) }\end{array}$ & GPT & OLS-Reg. & $\begin{array}{l}\text { Revenue, } \\
\text { productivity, } \\
\text { geography, } \\
\text { whether a } \\
\text { Top10 firm }\end{array}$ & Mark-up value & $\begin{array}{l}\text { Chinese wine firms located } \\
\text { in famous wine-producing } \\
\text { areas have considerable } \\
\text { market power and the } \\
\text { sector is an oligopoly (firms } \\
\text { with high market power } \\
\text { determine their prices). }\end{array}$ \\
\hline $\begin{array}{l}\text { Annunziata } \\
\text { et al. (2018) }\end{array}$ & $\begin{array}{l}\text { RBV, } \\
\text { EIT }\end{array}$ & SEM & $\begin{array}{l}\text { SC } \\
\text { collaboration, } \\
\text { innovation } \\
\text { capacity, } \\
\text { technology } \\
\text { adoption, } \\
\text { proactive } \\
\text { environmental } \\
\text { practices (PEP) }\end{array}$ & $\begin{array}{l}\text { Financial } \\
\text { performance }\end{array}$ & $\begin{array}{l}\text { SC Collaboration and } \\
\text { innovation capacity } \\
\text { positively correlate with } \\
\text { PEP. PEP positively } \\
\text { correlates with financial } \\
\text { performance and positively } \\
\text { mediates the relationships } \\
\text { between SC collaboration } \\
\text { and financial performance, } \\
\text { and 2) product innovation } \\
\text { and financial performance. }\end{array}$ \\
\hline
\end{tabular}




\begin{tabular}{|c|c|c|c|c|c|}
\hline Paper & Theory & Methodology & $\begin{array}{l}\text { Independent } \\
\text { Variable(s) }\end{array}$ & $\begin{array}{l}\text { Dependent } \\
\text { Variable(s) }\end{array}$ & Contribution \\
\hline $\begin{array}{l}\text { Galbreath et } \\
\text { al. (2016) }\end{array}$ & $\begin{array}{l}\text { RBV, } \\
\text { GPT, } \\
\text { OLT }\end{array}$ & SEM & $\begin{array}{l}\text { Absorptive } \\
\text { capacity, eco- } \\
\text { innovations, } \\
\text { knowledge } \\
\text { exchange }\end{array}$ & $\begin{array}{l}\text { Firm } \\
\text { outcomes }\end{array}$ & $\begin{array}{l}\text { Absorptive capacity is } \\
\text { positively associated with } \\
\text { eco-innovation and } \\
\text { knowledge exchanges (KE). } \\
\text { KE is positively related to } \\
\text { eco-innovations. KE } \\
\text { partially mediates the effect } \\
\text { of absorptive capacity on } \\
\text { eco-innovations. Eco- } \\
\text { innovations are positively } \\
\text { related to firm outcomes. }\end{array}$ \\
\hline $\begin{array}{l}\text { Giacomarra } \\
\text { et al. (2016) }\end{array}$ & QT & T-test & $\begin{array}{l}\text { Voluntary } \\
\text { certification }\end{array}$ & $\begin{array}{l}\text { Labor } \\
\text { productivity, } \\
\text { wine } \\
\text { exhibition } \\
\text { participation }\end{array}$ & $\begin{array}{l}\text { Certified wine firms exhibit } \\
\text { better economic } \\
\text { performance measured in } \\
\text { terms of labor productivity } \\
\text { and wine exhibition } \\
\text { participation. }\end{array}$ \\
\hline $\begin{array}{l}\text { Stasi et al. } \\
(2016)\end{array}$ & $\begin{array}{l}\text { RBV, } \\
\text { EIT }\end{array}$ & Log.-Reg. & $\begin{array}{l}\text { Regulations, } \\
\text { demand, } \\
\text { technology } \\
\text { push factors }\end{array}$ & $\begin{array}{l}\text { Innovative } \\
\text { technologies }\end{array}$ & $\begin{array}{l}\text { Voluntary environmental } \\
\text { certification and networking } \\
\text { positively correlate with } \\
\text { innovation. }\end{array}$ \\
\hline $\begin{array}{l}\text { Vidoli et al. } \\
\text { (2016) }\end{array}$ & GPT & SSFA & $\begin{array}{l}\text { Labor, } \\
\text { machinery, } \\
\text { water, energy, } \\
\text { fuel, land, } \\
\text { whether a } \\
\text { family firm, } \\
\text { gender, } \\
\text { subsidies, } \\
\text { diversification }\end{array}$ & $\begin{array}{l}\text { Production } \\
\text { output }\end{array}$ & $\begin{array}{l}\text { Based on analysis of FADN } \\
\text { survey results in Italy, } \\
\text { smaller firms tend to share } \\
\text { more tacit knowledge, } \\
\text { locating themselves at the } \\
\text { center of KNs. Large firms } \\
\text { choose to stay at the } \\
\text { periphery, share less } \\
\text { knowledge within the local } \\
\text { KN in a highly selective } \\
\text { manner. }\end{array}$ \\
\hline $\begin{array}{l}\text { Hojman } \\
\text { (2015) }\end{array}$ & $\mathrm{KBV}$ & $\begin{array}{l}\text { Ordered } \\
\text { Probit }\end{array}$ & $\begin{array}{l}\text { Firm age, export } \\
\text { orientation, } \\
\text { networking, } \\
\text { ownership, } \\
\text { consulting, } \\
\text { employing } \\
\text { expert } \\
\text { winemaker, } \\
\text { award winner }\end{array}$ & $\begin{array}{l}\text { Whether a } \\
\text { firm is an LC } \\
\text { Innovator, the } \\
\text { year a firm } \\
\text { listed as LC } \\
\text { innovator for } \\
\text { the first time }\end{array}$ & $\begin{array}{l}\text { Foreign influence, the long- } \\
\text { term presence of a senior } \\
\text { expert winemaker, and } \\
\text { participation in } \\
\text { international competitions } \\
\text { are positively related to } \\
\text { innovation activities. }\end{array}$ \\
\hline $\begin{array}{l}\text { Ahn et al. } \\
\text { (2013) }\end{array}$ & $\begin{array}{l}\mathrm{KBV} \\
\mathrm{OIT}\end{array}$ & SEM & $\begin{array}{l}\text { Inventive, } \\
\text { absorptive, } \\
\text { transformative, } \\
\text { connective, } \\
\text { innovative, } \\
\text { desorptive } \\
\text { capacity }\end{array}$ & Sales, profit & $\begin{array}{l}\text { Ol capacities are } \\
\text { significantly associated with } \\
\text { financial performance. Note: } \\
\text { Although not directly } \\
\text { related to wine, the } \\
\text { classification of capacities } \\
\text { based on Ol is useful for } \\
\text { wine studies. }\end{array}$ \\
\hline $\begin{array}{l}\text { Muscio et al. } \\
\text { (2015) }\end{array}$ & EIT & Log.-Reg. & $\begin{array}{l}\text { Regulatory } \\
\text { aspects, } \\
\text { demand factors, } \\
\text { firm \& } \\
\text { technology } \\
\text { factors, geo- } \\
\text { economic } \\
\text { factors }\end{array}$ & $\begin{array}{l}\text { Adopting } \\
\text { cleaner } \\
\text { production } \\
\text { (CP) and end- } \\
\text { of-pipe } \\
\text { technologies } \\
\text { (EOP) }\end{array}$ & $\begin{array}{l}\text { Regulation and access to } \\
\text { knowledge positively } \\
\text { correlate with eco- } \\
\text { innovation efforts. }\end{array}$ \\
\hline $\begin{array}{l}\text { Dries et al. } \\
(2014)\end{array}$ & $\begin{array}{l}\text { RBV, } \\
\text { OIT }\end{array}$ & $\begin{array}{l}\text { Multivariate } \\
\text { Probit }\end{array}$ & $\begin{array}{l}\text { Dynamic } \\
\text { (absorptive and } \\
\text { adaptive) } \\
\text { capabilities }\end{array}$ & $\begin{array}{l}\text { Open } \\
\text { innovation }\end{array}$ & $\begin{array}{l}\text { Both regional and company- } \\
\text { specific factors affect open } \\
\text { innovation. }\end{array}$ \\
\hline
\end{tabular}




\begin{tabular}{|c|c|c|c|c|c|}
\hline Paper & Theory & Methodology & $\begin{array}{l}\text { Independent } \\
\text { Variable(s) }\end{array}$ & $\begin{array}{l}\text { Dependent } \\
\text { Variable(s) }\end{array}$ & Contribution \\
\hline $\begin{array}{l}\text { Doloreux \& } \\
\text { Lord-Tarte } \\
(2013)\end{array}$ & OIT & EDA, NPT & $\begin{array}{l}\text { Open } \\
\text { innovation } \\
\text { strategy }\end{array}$ & $\begin{array}{l}\text { Innovation } \\
\text { capacity }\end{array}$ & $\begin{array}{l}\text { Adopting open innovation } \\
\text { strategy through } \\
\text { collaborations has a higher } \\
\text { impact on innovation } \\
\text { development and R\&D } \\
\text { activities. }\end{array}$ \\
\hline
\end{tabular}

\begin{tabular}{|c|c|c|c|c|c|}
\hline $\begin{array}{l}\text { Doloreux et } \\
\text { al. (2013) }\end{array}$ & $\begin{array}{l}\text { OIT, } \\
\text { GPT, } \\
\text { RBV }\end{array}$ & $\begin{array}{l}\text { PCA } \\
\text { Clustering } \\
\text { NPT }\end{array}$ & $\begin{array}{l}\text { Types of } \\
\text { innovation, } \\
\text { innovation } \\
\text { activities, } \\
\text { sources of } \\
\text { knowledge }\end{array}$ & $\begin{array}{l}\text { Clustering } \\
\text { wineries into } \\
\text { four } \\
\text { categories }\end{array}$ & $\begin{array}{l}\text { Wineries draw on a variety } \\
\text { of knowledge sources (i.e., } \\
\text { market, government, and } \\
\text { educational establishments) } \\
\text { to conduct product, process, } \\
\text { and organizational } \\
\text { innovation. }\end{array}$ \\
\hline
\end{tabular}

\begin{tabular}{|c|c|c|c|c|c|}
\hline $\begin{array}{l}\text { Leenders \& } \\
\text { Chandra } \\
(2013)\end{array}$ & EIT & Hier.-Reg. & $\begin{array}{l}\text { Internal \& } \\
\text { external drivers }\end{array}$ & $\begin{array}{l}\text { Green } \\
\text { innovation \& } \\
\text { business } \\
\text { performance }\end{array}$ & $\begin{array}{l}\text { Internal drivers are more } \\
\text { important. Green innovation } \\
\text { improves business } \\
\text { performance and DTC sales } \\
\text { capability moderates the } \\
\text { relationship between green } \\
\text { innovation and }\end{array}$ \\
\hline
\end{tabular}

\begin{tabular}{|c|c|c|c|c|c|}
\hline $\begin{array}{l}\text { Muscio et al. } \\
\text { (2013) }\end{array}$ & EIT & Log.-Reg. & $\begin{array}{l}\text { Structural } \\
\text { characteristics, } \\
\text { Innovation } \\
\text { activity, } \\
\text { outward } \\
\text { orientation, } \\
\text { marketing } \\
\text { strategies }\end{array}$ & $\begin{array}{l}\text { Adoption of } \\
\text { eco- } \\
\text { innovations }\end{array}$ & $\begin{array}{l}\text { Business characteristics, } \\
\text { firms' scientific search } \\
\text { processes, and innovative } \\
\text { behavior are key drivers of } \\
\text { innovation. }\end{array}$ \\
\hline $\begin{array}{l}\text { Atkin et al. } \\
\text { (2012) }\end{array}$ & ST & $\begin{array}{l}\text { Survey, EDA, } \\
\text { ANOVA }\end{array}$ & $\begin{array}{l}\text { The business } \\
\text { case for } \\
\text { environmental } \\
\text { management } \\
\text { system (EMS) }\end{array}$ & $\begin{array}{l}\text { Cost } \\
\text { advantage, } \\
\text { differentiation } \\
\text { advantage, } \\
\text { superior } \\
\text { operating } \\
\text { performance }\end{array}$ & $\begin{array}{l}\text { Respondents who have } \\
\text { completed EMS cases } \\
\text { exhibited significantly } \\
\text { higher cost leadership and } \\
\text { differentiation advantages } \\
\text { over those who have not } \\
\text { completed the case. }\end{array}$ \\
\hline $\begin{array}{l}\text { Chrisman \& } \\
\text { Patel (2012) }\end{array}$ & $\begin{array}{l}\text { BAM, } \\
\text { MLA }\end{array}$ & $\begin{array}{l}\text { Two-stage } \\
\text { OLS-Reg. }\end{array}$ & $\begin{array}{l}\text { Family firm } \\
\text { measures, } \\
\text { performance } \\
\text { aspiration gaps, } \\
\text { interactions }\end{array}$ & $\begin{array}{l}\text { R\&D } \\
\text { investment, } \\
\text { R\&D } \\
\text { variability }\end{array}$ & $\begin{array}{l}\text { Family firms invest less in } \\
\text { R\&D than non-family firms, } \\
\text { due to myopic aversion. } \\
\text { However, when } \\
\text { performance is below } \\
\text { aspiration levels, family } \\
\text { firms spend more money on } \\
\text { R\&D than non-family firms, } \\
\text { and variability in their R\&D } \\
\text { decreases due to their long- } \\
\text { term investment } \\
\text { orientation. Note: Although } \\
\text { not a wine study, findings } \\
\text { can be generalized for } \\
\text { family firms, including wine } \\
\text { firms. }\end{array}$ \\
\hline $\begin{array}{l}\text { Moreno et al. } \\
\text { (2011) }\end{array}$ & KBV & OLS-Reg. & $\begin{array}{l}\text { Technological } \\
\text { posture, firm } \\
\text { size, firm age, } \\
\text { product \& } \\
\text { process } \\
\text { innovation, } \\
\text { internal } \\
\text { \&external } \\
\text { sources, } \\
\text { innovative } \\
\text { effort }\end{array}$ & $\begin{array}{l}\text { Business } \\
\text { performance }\end{array}$ & $\begin{array}{l}\text { Technological posture, firm } \\
\text { size, firm age, product \& } \\
\text { process innovation, internal } \\
\text { sources, and innovative } \\
\text { efforts are positively } \\
\text { correlated with business } \\
\text { performance. }\end{array}$ \\
\hline
\end{tabular}




\begin{tabular}{|c|c|c|c|c|c|}
\hline Paper & Theory & Methodology & $\begin{array}{l}\text { Independent } \\
\text { Variable(s) }\end{array}$ & $\begin{array}{l}\text { Dependent } \\
\text { Variable(s) }\end{array}$ & Contribution \\
\hline $\begin{array}{l}\text { Giuliani \& } \\
\text { Arza (2009) }\end{array}$ & $\mathrm{KBV}$ & $\begin{array}{l}\text { Two-stage } \\
\text { Probit OLS }\end{array}$ & $\begin{array}{l}\text { KB of firms, } \\
\text { university } \\
\text { scientific quality }\end{array}$ & $\begin{array}{l}\text { University- } \\
\text { Industry link, } \\
\text { diffusion of } \\
\text { innovation }\end{array}$ & $\begin{array}{l}\text { In Chile, the stronger the } \\
\text { KBs and higher the } \\
\text { university's scientific } \\
\text { quality, the more likely a } \\
\text { firm-university linkage. The } \\
\text { results are reversed for } \\
\text { Italy. In both countries, the } \\
\text { stronger the KBs with } \\
\text { linkages to universities, the } \\
\text { higher the diffusion of } \\
\text { innovation. }\end{array}$ \\
\hline $\begin{array}{l}\text { Maurel } \\
\text { (2009) }\end{array}$ & RBV & $\begin{array}{l}\text { EDA, OLS- } \\
\text { Reg. }\end{array}$ & $\begin{array}{l}\text { Internal, } \\
\text { external, and } \\
\text { strategy related } \\
\text { determinants }\end{array}$ & $\begin{array}{l}\text { Export } \\
\text { performance }\end{array}$ & $\begin{array}{l}\text { Business partnerships, } \\
\text { innovation, greater firm size, } \\
\text { and effective export } \\
\text { commitment are linked to } \\
\text { higher export performance. }\end{array}$ \\
\hline $\begin{array}{l}\text { Murovec \& } \\
\text { Prodan } \\
(2008)\end{array}$ & $\mathrm{KBV}$ & PCA, SEM & $\begin{array}{l}\text { Absorptive } \\
\text { capacity }\end{array}$ & $\begin{array}{l}\text { Product or } \\
\text { process } \\
\text { innovation }\end{array}$ & $\begin{array}{l}\text { Absorptive capacity is } \\
\text { positively related to both } \\
\text { product and process } \\
\text { innovation. }\end{array}$ \\
\hline $\begin{array}{l}\text { Bruwer \& Li } \\
(2007)\end{array}$ & CBT & $\begin{array}{l}\text { CATI, } \\
\text { Clustering, } \\
\text { PCA }\end{array}$ & $\begin{array}{l}\text { Consumer } \\
\text { characteristics } \\
\text { (connoisseur, } \\
\text { information use, } \\
\text { occasion, } \\
\text { loyalty, etc.) }\end{array}$ & $\begin{array}{l}\text { Consumer } \\
\text { Segments }\end{array}$ & $\begin{array}{l}\text { Identifies } 5 \text { wine-related } \\
\text { lifestyle segments: } \\
\text { Conservative } \\
\text { knowledgeable drinkers, } \\
\text { enjoyment-oriented social } \\
\text { drinkers, basic drinkers, } \\
\text { mature time-rich drinkers, } \\
\text { 5) young professional } \\
\text { drinkers. }\end{array}$ \\
\hline $\begin{array}{l}\text { Garcia \& } \\
\text { Atkin (2007) }\end{array}$ & RIT & $\begin{array}{l}\text { ABM, } \\
\text { Conjoint } \\
\text { Simulation }\end{array}$ & $\begin{array}{l}\text { Co-opetition } \\
\text { strategy }\end{array}$ & $\begin{array}{l}\text { Consumer } \\
\text { adoption and } \\
\text { firm adoption } \\
\text { of screw caps } \\
\text { (Stelvins) }\end{array}$ & $\begin{array}{l}\text { The size of the alliance } \\
\text { significantly affects the rate } \\
\text { of innovation diffusion. As } \\
\text { the size of the alliance } \\
\text { grows, profit decreases. }\end{array}$ \\
\hline $\begin{array}{l}\text { Giuliani } \\
\text { (2007) }\end{array}$ & $\begin{array}{l}\text { GPT, } \\
\text { KBV }\end{array}$ & PCA SNA & $\mathrm{KB}$ of firms & $\begin{array}{l}\text { Normalized } \\
\text { degree cen- } \\
\text { trality }\end{array}$ & $\begin{array}{l}\text { Firms with stronger KBs are } \\
\text { likely to be more central in } \\
\text { the cluster KN. The } \\
\text { structure of the KN differs } \\
\text { significantly from that of } \\
\text { BN. The diffusion of } \\
\text { innovation in KNs is more } \\
\text { uneven than that of a BN. }\end{array}$ \\
\hline $\begin{array}{l}\text { Johnson \& } \\
\text { Bruwer } \\
(2007)\end{array}$ & CBT & Survey, EDA & $\begin{array}{l}\text { Regional } \\
\text { Branding }\end{array}$ & $\begin{array}{l}\text { Perceived } \\
\text { wine quality }\end{array}$ & $\begin{array}{l}\text { Regional branding is a multi- } \\
\text { faceted entity and positively } \\
\text { related to perceived wine } \\
\text { quality. }\end{array}$ \\
\hline $\begin{array}{l}\text { Giuliani \& } \\
\text { Bell (2005) }\end{array}$ & $\begin{array}{l}\text { KBV, } \\
\text { GPT }\end{array}$ & $\begin{array}{l}\text { PCA } \\
\text { Clustering } \\
\text { SNA }\end{array}$ & $\begin{array}{l}\text { Absorptive } \\
\text { capacity }\end{array}$ & $\begin{array}{l}\text { External } \\
\text { openness, } \\
\text { intra-cluster } \\
\text { knowledge } \\
\text { linkages } \\
\end{array}$ & $\begin{array}{l}\text { Knowledge in the network is } \\
\text { not diffused evenly but } \\
\text { flows among firms with } \\
\text { larger absorptive capacities. }\end{array}$ \\
\hline $\begin{array}{l}\text { Delacroix \& } \\
\text { Swaminathan } \\
\text { (1991) }\end{array}$ & OBT & EHA & $\begin{array}{l}\text { Organizational } \\
\& \\
\text { environmental } \\
\text { conditions }\end{array}$ & $\begin{array}{l}\text { Organizational } \\
\text { change \& } \\
\text { disbanding }\end{array}$ & $\begin{array}{l}\text { Large and older wineries are } \\
\text { more conservative and less } \\
\text { likely to disband, prior } \\
\text { change is a good predictor } \\
\text { of future change. }\end{array}$ \\
\hline
\end{tabular}


Table A3. List of Qualitative Studies

\begin{tabular}{|c|c|c|c|}
\hline Paper & Theory & Methodology & Contribution \\
\hline $\begin{array}{l}\text { Carlsen } \\
(2004)\end{array}$ & & Conceptual & $\begin{array}{l}\text { Proposes a framework that places wine production and tourism on } \\
\text { opposite ends of the industrial spectrum. The former is a supply-driven, } \\
\text { product-oriented sector focused on capital growth, whereas the latter is a } \\
\text { demand-driven profit-maximizing service sector. }\end{array}$ \\
\hline $\begin{array}{l}\text { Cardebat } \\
\text { et al. } \\
(2020)\end{array}$ & & $\begin{array}{l}\text { Review, } \\
\text { Commentary }\end{array}$ & $\begin{array}{l}\text { Points out that COVID-19 leads to uncertainty in the wine sector in } \\
\text { inventory management and distribution. Drawing attention to changes in } \\
\text { consumption patterns, authors predict that companies that serve large } \\
\text { domestic markets, produce quality-driven terroir wines, and have solid } \\
\text { direct sales capabilities would perform better. }\end{array}$ \\
\hline $\begin{array}{l}\text { Choi \& Gu } \\
(2020)\end{array}$ & $\begin{array}{l}\text { GPT, } \\
\text { KBV }\end{array}$ & GNA & $\begin{array}{l}\text { Provides evolution of wine-related knowledge creation in China between } \\
2007 \text { and } 2016 \text { using patent data and GNA. The success industry was } \\
\text { assigned to joint ventures with the US, Italy, Germany, France, and Canada, } \\
\text { government-led development plans, and government policies that promote } \\
\text { industry-university collaboration. }\end{array}$ \\
\hline $\begin{array}{l}\text { Colbert et } \\
\text { al. }(2020)\end{array}$ & & Commentary & $\begin{array}{l}\text { Draws attention to a recent increase in online alcohol sales and home } \\
\text { delivery in Australia. States that online retailers are subject to less } \\
\text { regulation, which leads to problems such as leaving alcohol unattended } \\
\text { without age verification, an increase in family violence, and self-harm. }\end{array}$ \\
\hline $\begin{array}{l}\text { Karagiannis } \\
\& \text { Metaxas } \\
(2020)\end{array}$ & ST & Survey, EDA & $\begin{array}{l}\text { Surveying managers of } 41 \text { SMEs in Greece, makes recommendations on } \\
\text { sustainable wine tourism development. Only } 22 \% \text { of wineries offer online } \\
\text { sales and } \% 50 \text { of wineries accept credit card payments. The sector largely } \\
\text { relies on on-site sales ( } 83 \%) \text {. }\end{array}$ \\
\hline $\begin{array}{l}\text { Z. Li et al. } \\
(2020)\end{array}$ & $\begin{array}{l}\text { PDT, } \\
\text { CLT }\end{array}$ & Conceptual & $\begin{array}{l}\text { Discusses the impact of COVID-19 on tourist behavior (indirect effect on } \\
\text { on-premise sales in countries that rely on tourism). }\end{array}$ \\
\hline $\begin{array}{l}\text { Laguna et } \\
\text { al. }(2020)\end{array}$ & SNT & Survey, SMA & $\begin{array}{l}\text { Investigates the impact of COVID-19 on consumer food \& beverage } \\
\text { preferences by using SMA and an online questionnaire. Finds a reduction } \\
\text { in shopping frequency. No changes in shopping location. } 27.7 \% \text { of } \\
\text { consumers report an increase in their wine \& beer spending, and } 30 \% \\
\text { reported a decrease. }\end{array}$ \\
\hline $\begin{array}{l}\text { Neufeld et } \\
\text { al. (2020) }\end{array}$ & & Commentary & $\begin{array}{l}\text { Discusses risks associated with the increasing availability of alcohol via } \\
\text { online sales and home delivery, loosening of regulation, and diversion of } \\
\text { alcoholic beverages for other purposes (i.e., disinfectants) during the } \\
\text { pandemic. }\end{array}$ \\
\hline $\begin{array}{l}\text { Ouvrard et } \\
\text { al. }(2020)\end{array}$ & & Interview & $\begin{array}{l}\text { Based on } 11 \text { interviewees from France and Italy, the authors identify four } \\
\text { elements, namely performance, resources, innovation, and value creation, } \\
\text { as essential factors that make up a sustainable business model. }\end{array}$ \\
\hline $\begin{array}{l}\text { Soceanu et } \\
\text { al. (2020) }\end{array}$ & EIT, ST & $\begin{array}{l}\text { Lab } \\
\text { Experiment, } \\
\text { Case Study }\end{array}$ & $\begin{array}{l}\text { Proposes a method to recover waste from winemaking for better } \\
\text { economic, social and environmental performance. }\end{array}$ \\
\hline $\begin{array}{l}\text { Št’astná et } \\
\text { al. (2020) }\end{array}$ & & Survey, IPA & $\begin{array}{l}\text { Based on } 271 \text { survey responses from Czechia, authors classify various } \\
\text { aspects of wine tourism into four major performance categories } \\
\text { (Concentrate here, keep up the good work, low priority, and possible } \\
\text { overkill) via IPA analysis. }\end{array}$ \\
\hline $\begin{array}{l}\text { Ugaglia \& } \\
\text { Ouvrard } \\
(2020)\end{array}$ & QT, ST & $\begin{array}{l}\text { Case Study, } \\
\text { Interview }\end{array}$ & $\begin{array}{l}\text { Discussing a product differentiation strategy of a French wine company } \\
\text { that seeks to improve quality via innovation and sustainability while } \\
\text { respecting tradition. }\end{array}$ \\
\hline $\begin{array}{l}\text { Vergamini } \\
\text { et al. } \\
(2020)\end{array}$ & RT & $\begin{array}{l}\text { Review, } \\
\text { MMPR }\end{array}$ & $\begin{array}{l}\text { Analyzes the impact of the pandemic on the wine sector in Italy, Spain, } \\
\text { Portugal, France, Australia, and the US, distinguishing between short- and } \\
\text { long-term implications. Makes recommendations on improving resiliency. } \\
\text { Notes that in the short term, wineries that rely on tourism are likely to be } \\
\text { affected the most. }\end{array}$ \\
\hline $\begin{array}{l}\text { Porto- } \\
\text { Gómez et } \\
\text { al. (2020) }\end{array}$ & & $\begin{array}{l}\text { Literature } \\
\text { Review }\end{array}$ & $\begin{array}{l}\text { Using a bibliometric review approach identifies sustainable innovation as } \\
\text { the emerging distinct type of innovation in the wine industry. }\end{array}$ \\
\hline $\begin{array}{l}\text { Cradock- } \\
\text { Henry \& } \\
\text { Fountain } \\
(2019)\end{array}$ & SEPR & $\begin{array}{l}\text { Case Study, } \\
\text { Conceptual }\end{array}$ & $\begin{array}{l}\text { Investigates the socio-economic impact of a recent earthquake on New } \\
\text { Zealand's wine sector and makes recommendations on improving the } \\
\text { resilience of wine supply chains. }\end{array}$ \\
\hline
\end{tabular}




\begin{tabular}{|c|c|c|c|}
\hline Paper & Theory & Methodology & Contribution \\
\hline $\begin{array}{l}\text { Pabst et al. } \\
\text { (2019) }\end{array}$ & CBT & $\begin{array}{l}\text { Survey, } \\
\text { Interview }\end{array}$ & $\begin{array}{l}\text { Wine producers in Germany believe that the EU's mandatory nutrition } \\
\text { labeling policy will create consumer confusion and uncertainty, increase } \\
\text { production costs, and create opportunities for wineries that focus on clean } \\
\text { labeling to completely avoid additives that require labeling. }\end{array}$ \\
\hline $\begin{array}{l}\text { Gault } \\
(2018)\end{array}$ & SP & EDA & $\begin{array}{l}\text { Proposes a general definition of innovation. "Innovation is the } \\
\text { implementation of a new or significantly changed product or process. A } \\
\text { product is a good or service. The process includes production or delivery, } \\
\text { organization, and marketing processes." }\end{array}$ \\
\hline $\begin{array}{l}\text { Humphreys } \\
\& \\
\text { Carpenter } \\
\text { (2018) }\end{array}$ & $\begin{array}{l}\text { SP, } \\
\text { RBV, } \\
\text { SIT }\end{array}$ & Interview & $\begin{array}{l}\text { Points out that winemaking is more of an art than a science and customer } \\
\text { preferences can easily be influenced due to unique market conditions (i.e., } \\
\text { high ambiguity and complexity, noisy consumer learning, and limited } \\
\text { consumer expertise). Unlike market-driven firms that use consumer data to } \\
\text { develop innovative products and strategies, market driving firms do not } \\
\text { focus on consumers and innovation at all, they just play a "status game" to } \\
\text { shape consumer preferences by developing a vision, employing celebrity } \\
\text { winemakers, influencing critics, and media, affecting retail sales by } \\
\text { promoting scores by critics, and form alliances to enhance their status. }\end{array}$ \\
\hline $\begin{array}{l}\text { H. Li et al. } \\
(2018)\end{array}$ & & $\begin{array}{l}\text { Historical } \\
\text { Analysis }\end{array}$ & $\begin{array}{l}\text { Proposes that China should be classified as an "Ancient" wine producer, } \\
\text { presenting some historical evidence and information about Chinese wine } \\
\text { culture and history. States that China is currently classified in neither New } \\
\text { World nor Old World. }\end{array}$ \\
\hline $\begin{array}{l}\text { Scaringella } \\
\& \\
\text { Radziwon } \\
(2018)\end{array}$ & & $\begin{array}{l}\text { Literature } \\
\text { review }\end{array}$ & $\begin{array}{l}\text { Classifies } 104 \text { studies and links four main ecosystems (i.e., business, } \\
\text { innovation, entrepreneurial, and knowledge systems) and territorial } \\
\text { approaches under an evolutionary system theory and proposes a } \\
\text { theoretical framework. }\end{array}$ \\
\hline $\begin{array}{l}\text { Y. Li \& } \\
\text { Bardají } \\
(2017)\end{array}$ & & SWOT, EDA & $\begin{array}{l}\text { Provides a detailed SWOT analysis of the Chinese wine industry and makes } \\
\text { a series of recommendations on improving the performance of the industry } \\
\text { focusing on domestic sales. }\end{array}$ \\
\hline $\begin{array}{l}\text { Morrison \& } \\
\text { Rabellotti } \\
\text { (2017) }\end{array}$ & $\begin{array}{l}\text { CU, } \\
\text { WO }\end{array}$ & $\begin{array}{l}\text { Comparative } \\
\text { Study, EDA }\end{array}$ & $\begin{array}{l}\text { Analyzes the evolution of the wine industry from } 1960 \text { to } 2010 \text {, comparing } \\
\text { old and new world countries' performances based on production volume, } \\
\text { consumption, export volume, export value, and unite export value, to } \\
\text { explain why catch-up is slower than other industries. }\end{array}$ \\
\hline $\begin{array}{l}\text { Signori et } \\
\text { al. (2017) }\end{array}$ & GT & Interview & $\begin{array}{l}\text { Identifies four major barriers to sustainable innovation: competing } \\
\text { motivations, innovation focus and styles, lack of sustainability orientation, } \\
\text { and lack of resources and capabilities. }\end{array}$ \\
\hline $\begin{array}{l}\text { Woodfield } \\
\text { \& Husted } \\
\text { (2017) }\end{array}$ & KBV & $\begin{array}{l}\text { Case study, } \\
\text { Interview }\end{array}$ & $\begin{array}{l}\text { In family firms, successors not only receive experience-based knowledge } \\
\text { from incumbents but are also the sources of new knowledge gained via } \\
\text { education. Firms that facilitate bi-directional tacit information sharing } \\
\text { between the two generations may achieve greater benefits in terms of } \\
\text { innovation. }\end{array}$ \\
\hline $\begin{array}{l}\text { Gilinsky et } \\
\text { al. (2016) }\end{array}$ & ST & $\begin{array}{l}\text { Case Study, } \\
\text { Interview }\end{array}$ & $\begin{array}{l}\text { Family firms in the wine sector are long-term performance-oriented: the } \\
\text { number one priority for incumbent managers is "leaving the land in better } \\
\text { shape for next generations." }\end{array}$ \\
\hline $\begin{array}{l}\text { Sacchelli et } \\
\text { al. (2016) }\end{array}$ & & $\begin{array}{l}\text { Content } \\
\text { Analysis, Text } \\
\text { Mining }\end{array}$ & $\begin{array}{l}\text { Wine research focuses mostly on the socio-economic impacts of climate } \\
\text { change. Ecological aspects are often ignored. Adaptation and defensive } \\
\text { strategies are in their initial stages. Temperature control and water deficit } \\
\text { strategies are proposed. Future research should focus on uncertainty } \\
\text { analysis. Australia, the US, and the EU attach greater importance to } \\
\text { sustainability than China and South Africa. Terroir and quality issues are } \\
\text { primarily discussed in French and Italian studies. }\end{array}$ \\
\hline $\begin{array}{l}\text { Schimmenti } \\
\text { et al. } \\
(2016) \\
\end{array}$ & & EDA & $\begin{array}{l}\text { Investigates adoption of sustainable entrepreneurship practices by the } \\
\text { three wine producers in Sicily that participate in SOStain program. }\end{array}$ \\
\hline $\begin{array}{l}\text { Rodríguez- } \\
\text { Méndez et } \\
\text { al. (2016) }\end{array}$ & & $\begin{array}{l}\text { Literature } \\
\text { Review }\end{array}$ & $\begin{array}{l}\text { E-tongues and e-noses are widely used in the wine industry to assess the } \\
\text { quality of grapes and crushing, to monitor the fermentation and aging, to } \\
\text { analyze nano-oxygenation due to corks in bottling, to classify grape } \\
\text { varieties and their geographic origin, to detect spoilage, off-odors, frauds, } \\
\text { and adulterations, and to assess various chemical parameters. Despite } \\
\text { recent developments, e-tongues and e-noses still perform worse than a } \\
\text { panel of human wine experts. }\end{array}$ \\
\hline $\begin{array}{l}\text { Vrontis et } \\
\text { al. }(2016)\end{array}$ & CBT & $\begin{array}{l}\text { Case Study, } \\
\text { Interview }\end{array}$ & $\begin{array}{l}\text { Innovation and tradition are not mutually exclusive. Blending the two may } \\
\text { lead to a competitive advantage. }\end{array}$ \\
\hline
\end{tabular}




\begin{tabular}{|c|c|c|c|}
\hline Paper & Theory & Methodology & Contribution \\
\hline $\begin{array}{l}\text { Dressler } \\
\text { (2013) }\end{array}$ & RBV & Survey & $\begin{array}{l}\text { Wine companies in Germany mostly adopt innovation strategies related to } \\
\text { pricing. They spend more money on renovating old buildings and facilities } \\
\text { (i.e., creating fancy tasting rooms). They neglect innovations regarding } \\
\text { strategic sourcing, innovative services, and social media. }\end{array}$ \\
\hline $\begin{array}{l}\text { Vrontis et } \\
\text { al. (2011) }\end{array}$ & & $\begin{array}{l}\text { EDA, } \\
\text { Concep- tual }\end{array}$ & $\begin{array}{l}\text { Investigates the role that branding plays in Italian wine firms' local and } \\
\text { international competitiveness and consumer behavior (response) to wine } \\
\text { branding, and develops a conceptual framework named as Preliminary } \\
\text { Prescriptive Strategic Branding Framework. }\end{array}$ \\
\hline $\begin{array}{l}\text { Schultz \& } \\
\text { Jones } \\
\text { (2010) }\end{array}$ & ST & Review & $\begin{array}{l}\text { Examines the potential negative impacts of global warming on future wine } \\
\text { production. Authors predict that climate change is likely to change grape } \\
\text { varieties, grape compositions, the timing of growing, harvesting, and } \\
\text { production, as well as wine styles. }\end{array}$ \\
\hline $\begin{array}{l}\text { Van } \\
\text { Leeuwen \& } \\
\text { Seguin } \\
\text { (2006) }\end{array}$ & ST & Review & $\begin{array}{l}\text { Explains the impact of terroir on producing high-quality wines. Making a } \\
\text { distinction between terroir wines and branded wines, authors state that } \\
\text { contrary to branded wines, the volume of terroir wines cannot be easily } \\
\text { increased. }\end{array}$ \\
\hline $\begin{array}{l}\text { Alant \& } \\
\text { Bruwer } \\
(2004)\end{array}$ & CBT & $\begin{array}{l}\text { Survey, FAM, } \\
\text { QA }\end{array}$ & $\begin{array}{l}\text { Based on analysis of survey results, proposes a conceptual motivational } \\
\text { framework that explains wine tourist behavior. The framework has three } \\
\text { dimensions (visitor, wine region, visit dynamic) and three sub-dimensions. }\end{array}$ \\
\hline $\begin{array}{l}\text { Vaudour } \\
\text { (2002) }\end{array}$ & & $\begin{array}{l}\text { Literature } \\
\text { Review }\end{array}$ & $\begin{array}{l}\text { Proposes a more scientific definition of terroir, which excludes conscience } \\
\text { connotations. States that spatial modeling and GIS data can update the } \\
\text { concept of terroir. }\end{array}$ \\
\hline
\end{tabular}

\begin{tabular}{cccc}
\hline From Cohen's $d$ to $r$ & From $\log (\mathrm{OR})$ to Cohen's $d$ & From t-statistic to $r$ & From F-statistic to $r$ \\
\hline$r=\frac{d}{\sqrt{d^{2}+4}}$ & $d=\frac{\sqrt{3} \log (\mathrm{OR})}{\pi}$ & $r=\sqrt{\frac{t^{2}}{t^{2}+d f}}$ & $r=\sqrt{\frac{F}{F+d f}}$ \\
\hline From partial $\eta^{2}$ to $d$ & From Kendall's $\tau$ to $r$ & From $\log (\mathrm{OR})$ to OR & From probit $(\beta)$ to $\log (\mathrm{OR})$ \\
\hline$d=\sqrt{\frac{(n-1) \eta^{2}}{n\left(1-\eta^{2}\right)}}$ & $r=\sin \left(\frac{\pi \tau}{2}\right)$ & $O R=e^{\log (O R)}$ & $\log (O R)=1.7 \beta$ \\
\end{tabular}

Figure A2. Formulae used to convert between effect sizes 
Table A4. Effect Sizes Before and After Conversion

\begin{tabular}{|c|c|c|c|c|c|}
\hline \multicolumn{6}{|c|}{ Innovation \& Financial Performance } \\
\hline Author & Year & $\begin{array}{l}\text { Sample Size } \\
\text { (n) }\end{array}$ & $\begin{array}{c}\text { Reported Effect } \\
\text { Size }\end{array}$ & $\begin{array}{l}\text { Type of Effect } \\
\text { Size }\end{array}$ & $\begin{array}{l}\text { Effect Size After } \\
\text { Conversion }\end{array}$ \\
\hline Pradana et al. & 2020 & 138 & 0.255 & r & 0.255 \\
\hline Knight et al. & 2019 & 220 & 0.489 & r & 0.489 \\
\hline Annunziata et al. & 2018 & 357 & 0.533 & r & 0.533 \\
\hline Lorenzo et al. & 2018 & 339 & 0.226 & r & 0.226 \\
\hline $\begin{array}{l}\text { Guerrero-Villegas et al. } \\
\text { (2018) }\end{array}$ & 2018 & 121 & 1.950 & t statistic & 0.178 \\
\hline Galbreath & 2016 & 203 & 0.180 & r & 0.180 \\
\hline Stasi et al. & 2016 & 334 & 0.843 & Log odds ratio & 0.226 \\
\hline Chrisman \& Patell & 2012 & 964 & 0.090 & r & 0.090 \\
\hline Moreno et al. & 2011 & 102 & 0.142 & t statistic & 0.143 \\
\hline \multicolumn{6}{|c|}{ Absorptive Capacity \& Innovation } \\
\hline Author & Year & $\begin{array}{l}\text { Sample Size } \\
\text { (n) }\end{array}$ & $\begin{array}{l}\text { Reported Effect } \\
\text { Size }\end{array}$ & $\begin{array}{l}\text { Type of Effect } \\
\text { Size }\end{array}$ & $\begin{array}{l}\text { Effect Size After } \\
\text { Conversion }\end{array}$ \\
\hline Frigon et al. & 2020 & 151 & 1.120 & Log odds ratio & 0.295 \\
\hline Pradana et al. & 2020 & 138 & 0.232 & $r$ & 0.232 \\
\hline Doloreux et al. & 2020 & 151 & 0.305 & Log odds ratio & 0.084 \\
\hline Annunziata et al. & 2018 & 357 & 0.327 & $r$ & 0.327 \\
\hline Lorenzo et al. & 2018 & 339 & 0.133 & r & 0.133 \\
\hline Faccin et al. & 2017 & 104 & 0.720 & F statistic & 0.083 \\
\hline Presenza et al. & 2017 & 191 & 0.023 & $r$ & 0.023 \\
\hline Galbreath et al. & 2016 & 203 & 0.410 & $r$ & 0.410 \\
\hline Stasi et al. & 2016 & 334 & 2.041 & Log odds ratio & 0.490 \\
\hline Hojman & 2015 & 43 & 0.250 & $r$ & 0.250 \\
\hline Muscio et al. & 2015 & 334 & 0.585 & Log odds ratio & 0.159 \\
\hline Giuliani \& Arza & 2009 & 32 & 0.540 & r & 0.540 \\
\hline Giuliani \& Arza & 2009 & 41 & 0.460 & $r$ & 0.460 \\
\hline Giuliani \& Bell & 2005 & 32 & 0.523 & Kendall's tau & 0.732 \\
\hline \multicolumn{6}{|c|}{ Technology Adoption \& Innovation } \\
\hline Author & Year & $\begin{array}{l}\text { Sample Size } \\
\text { (n) }\end{array}$ & $\begin{array}{c}\text { Reported Effect } \\
\text { Size }\end{array}$ & $\begin{array}{l}\text { Type of Effect } \\
\text { Size }\end{array}$ & $\begin{array}{l}\text { Effect Size After } \\
\text { Conversion }\end{array}$ \\
\hline Frigon et al. & 2020 & 151 & 1.350 & Log odds ratio & 0.349 \\
\hline Annunziata et al. & 2018 & 357 & 0.427 & r & 0.427 \\
\hline Lorenzo et al. & 2018 & 339 & 0.074 & r & 0.074 \\
\hline Stasi et al. & 2016 & 334 & 2.041 & Log odds ratio & 0.490 \\
\hline \multicolumn{6}{|c|}{ Sustainable Practices \& Innovation } \\
\hline Author & Year & $\begin{array}{l}\text { Sample Size } \\
\text { (n) }\end{array}$ & $\begin{array}{c}\text { Reported Effect } \\
\text { Size }\end{array}$ & $\begin{array}{l}\text { Type of Effect } \\
\text { Size }\end{array}$ & $\begin{array}{l}\text { Effect Size After } \\
\text { Conversion }\end{array}$ \\
\hline Frigon et al. & 2020 & 151 & 0.890 & Log odds ratio & 0.238 \\
\hline Knight et al. & 2019 & 220 & 0.452 & r & 0.452 \\
\hline Annunziata et al. & 2018 & 357 & 0.276 & r & 0.276 \\
\hline Guerrero-Villegas et al. & 2018 & 121 & 4.430 & t statistic & 0.375 \\
\hline Fiore et al. & 2017 & 280 & 0.493 & r & 0.493 \\
\hline Stasi et al. & 2016 & 334 & 17.470 & Log odds ratio & 0.979 \\
\hline Galbreath et al. & 2016 & 203 & 0.490 & r & 0.490 \\
\hline Muscio et al. & 2015 & 334 & 0.339 & Log odds ratio & 0.093 \\
\hline
\end{tabular}




\begin{tabular}{|c|c|c|c|c|c|}
\hline \multicolumn{6}{|c|}{ Innovation \& Financial Performance } \\
\hline Author & Year & $\begin{array}{l}\text { Sample Size } \\
\text { (n) }\end{array}$ & $\begin{array}{l}\text { Reported Effect } \\
\text { Size }\end{array}$ & $\begin{array}{c}\text { Type of Effect } \\
\text { Size }\end{array}$ & $\begin{array}{l}\text { Effect Size After } \\
\text { Conversion }\end{array}$ \\
\hline Annunziata et al. & 2018 & 357 & 0.264 & r & 0.264 \\
\hline Presenza et al. & 2017 & 191 & -0.027 & Log odds ratio & -0.008 \\
\hline Galbreath et al. & 2016 & 203 & 0.020 & r & 0.020 \\
\hline Stasi et al. & 2016 & 334 & 0.455 & Log odds ratio & 0.124 \\
\hline Hojman & 2015 & 43 & 0.210 & r & 0.210 \\
\hline Muscio et al. & 2015 & 334 & -0.008 & Log odds ratio & -0.002 \\
\hline Maurel & 2009 & 82 & 0.164 & $\begin{array}{l}\text { Partial eta } \\
\text { squared }\end{array}$ & 0.216 \\
\hline \multicolumn{6}{|l|}{ Firm Size \& Innovation } \\
\hline Author & Year & $\begin{array}{c}\text { Sample Size } \\
\text { (n) }\end{array}$ & $\begin{array}{c}\text { Reported Effect } \\
\text { Size } \\
\end{array}$ & $\begin{array}{c}\text { Type of Effect } \\
\text { Size } \\
\end{array}$ & $\begin{array}{c}\text { Effect Size After } \\
\text { Conversion }\end{array}$ \\
\hline Frigon et al. & 2020 & 151 & 0.680 & Log odds ratio & 0.184 \\
\hline Pradana et al. & 2020 & 138 & 0.011 & r & 0.011 \\
\hline Doloreux et al. & 2020 & 151 & 0.557 & Log odds ratio & 0.152 \\
\hline Annunziata et al. & 2018 & 357 & 0.068 & r & 0.068 \\
\hline Guerrero-Villegas et al. & 2018 & 121 & 1.230 & t-statistic & 0.112 \\
\hline Galbreath et al. & 2016 & 203 & 0.150 & r & 0.150 \\
\hline Muscio et al. & 2013 & 47 & -0.030 & Log odds ratio & -0.008 \\
\hline Giuliani & 2007 & 105 & 0.429 & r & 0.429 \\
\hline \multicolumn{6}{|l|}{ Firm Age \& Innovation } \\
\hline Author & Year & $\begin{array}{c}\text { Sample Size } \\
\text { (n) }\end{array}$ & $\begin{array}{c}\text { Reported Effect } \\
\text { Size }\end{array}$ & $\begin{array}{c}\text { Type of Effect } \\
\text { Size }\end{array}$ & $\begin{array}{l}\text { Effect Size After } \\
\text { Conversion }\end{array}$ \\
\hline Frigon et al. & 2020 & 151 & 0.230 & Log odds ratio & 0.063 \\
\hline Annunziata et al. & 2018 & 357 & -0.049 & $r$ & -0.049 \\
\hline Guerrero-Villegas et al. & 2018 & 121 & 0.850 & t statistic & 0.077 \\
\hline Galbreath et al. & 2016 & 203 & 0.140 & $r$ & 0.140 \\
\hline Hojman & 2015 & 43 & 0.170 & r & 0.170 \\
\hline Chrisman \& Patel & 2012 & 964 & -0.110 & $r$ & -0.110 \\
\hline \multicolumn{6}{|c|}{ Links to Research Institutions \& Innovation } \\
\hline Author & Year & $\begin{array}{c}\text { Sample Size } \\
\text { (n) }\end{array}$ & $\begin{array}{c}\text { Reported Effect } \\
\text { Size } \\
\end{array}$ & $\begin{array}{c}\text { Type of Effect } \\
\text { Size } \\
\end{array}$ & $\begin{array}{c}\text { Effect Size After } \\
\text { Conversion }\end{array}$ \\
\hline Presenza et al. & 2017 & 191 & -0.059 & Log odds ratio & -0.016 \\
\hline Stasi et al. & 2016 & 334 & 0.216 & Log odds ratio & 0.059 \\
\hline Giuliani \& Arza & 2009 & 41 & 0.489 & $\begin{array}{c}\text { Probit } \\
\text { coefficient }\end{array}$ & 0.223 \\
\hline Giuliani \& Arza & 2009 & 32 & 0.114 & $\begin{array}{c}\text { Probit } \\
\text { coefficient }\end{array}$ & 0.053 \\
\hline
\end{tabular}



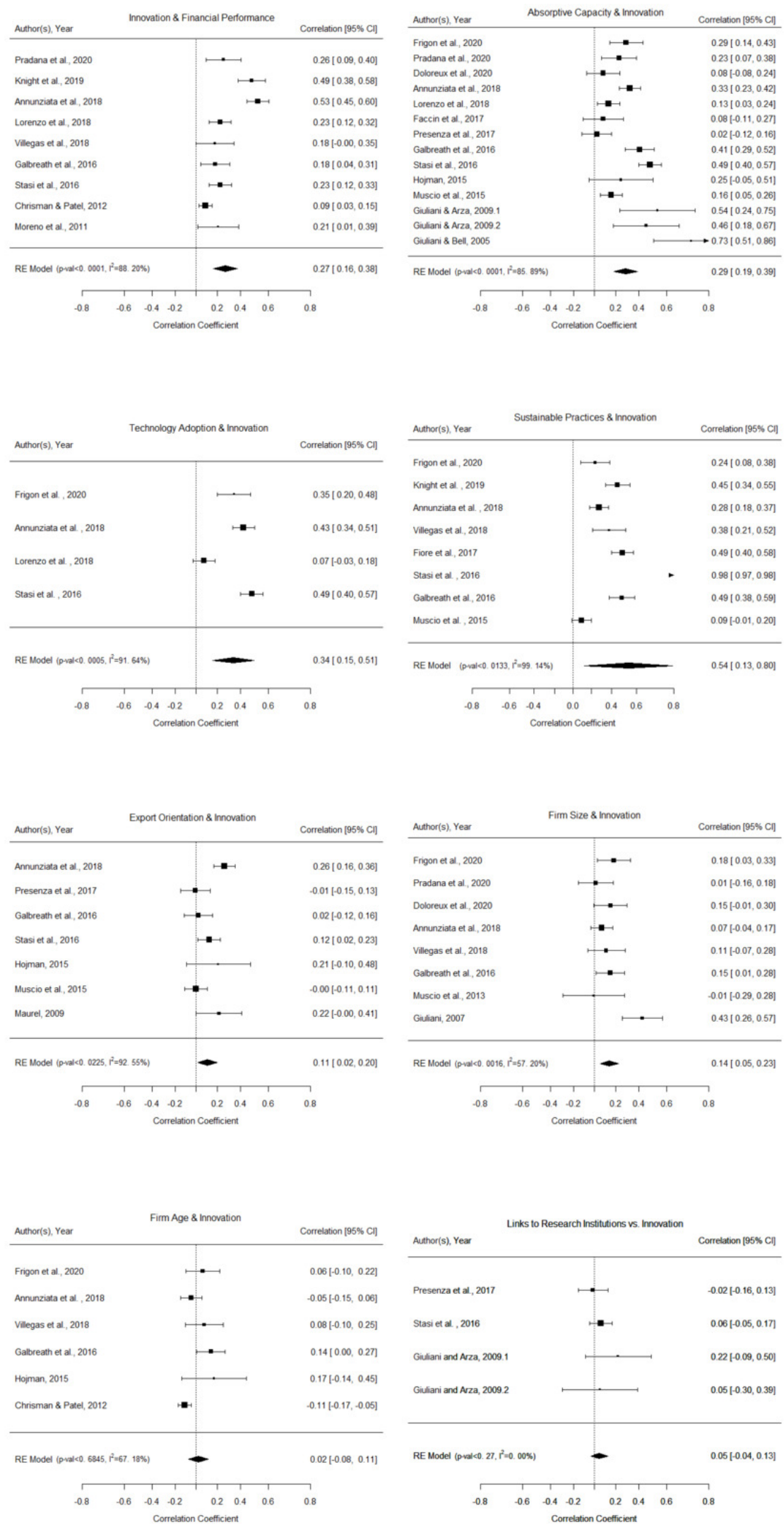

Figure A1. Forest Plots 

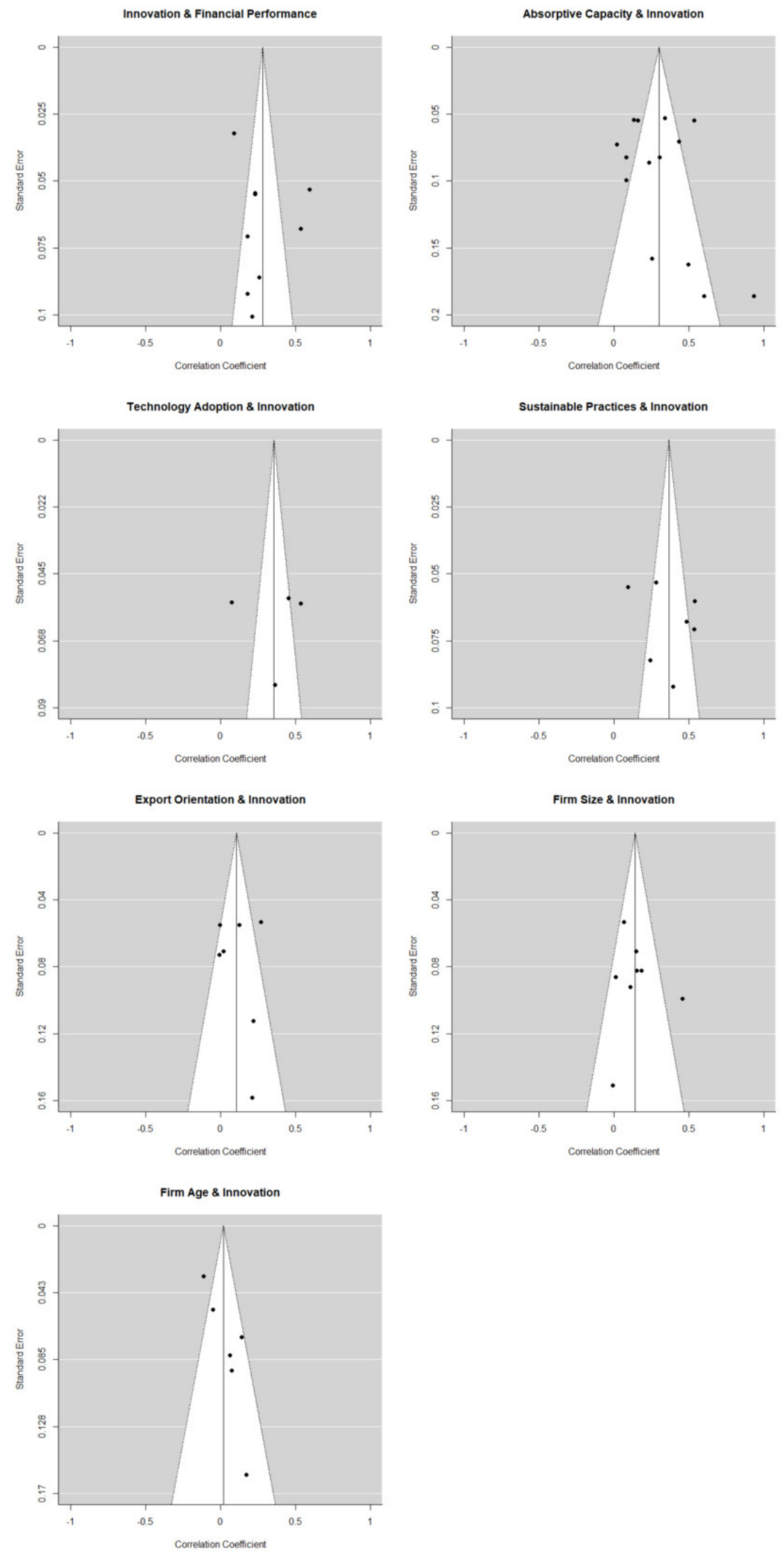

Figure A3. Funnel Plots 


\section{Supplementary Materials}

\section{Managerial Summary}

Download: https://wbcri.scholasticahq.com/article/31627-investigation-of-innovation-in-wine-industry-via-metaanalysis/attachment/79523.docx 